\title{
Next-generation biological control: the need for integrating genetics and genomics
}

Kelley Leung ${ }^{1 *} \odot$, Erica Ras ${ }^{2}$, Kim B. Ferguson ${ }^{3} \odot$, Simone Ariëns ${ }^{4}$, Dirk Babendreier ${ }^{5}$ ( , Piter Bijma ${ }^{6}{ }^{\oplus}$, Kostas Bourtzis ${ }^{2}{ }^{\oplus}$, Jacques Brodeur ${ }^{7}$, , Margreet A. Bruins $^{3}$, Alejandra Centurión ${ }^{4}$, Sophie R. Chattington ${ }^{4}{ }^{\oplus}$, Milena Chinchilla-Ramírez ${ }^{8}$ (),

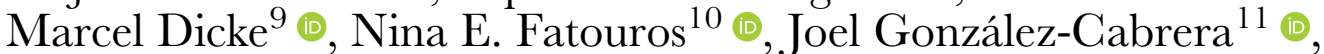
Thomas V. M. Groot ${ }^{12}$, Tim Haye ${ }^{5} \odot$, Markus Knapp ${ }^{12}$ ๑), Panagiota Koskinioti ${ }^{2,13} \odot$, Sophie Le Hesran ${ }^{9,12}$, Manolis Lyrakis ${ }^{14,15}$ (อ), Angeliki Paspati ${ }^{8}$ (0), Meritxell Pérez-Hedo $^{8}$ ๑, Wouter N. Plouvier ${ }^{16}$ @ , Christian Schlötterer $^{14}{ }^{\oplus}$,

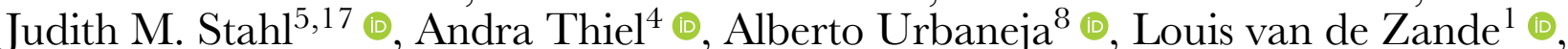

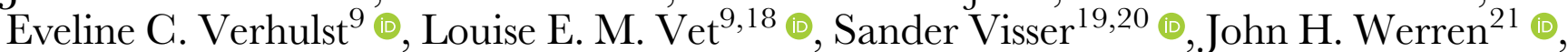
Shuwen Xia ${ }^{6}$, Bas J. Zwaan ${ }^{3} \odot$, Sara Magalhães ${ }^{22} \odot$, Leo W. Beukeboom ${ }^{1} \odot$ and Bart A. Pannebakker ${ }^{3}$ (1)

\footnotetext{
${ }^{1}$ Groningen Institute for Evolutionary Life Sciences, University of Groningen, PO Box 11103, 9700 CC, Groningen, The Netherlands

${ }^{2}$ Insect Pest Control Laboratory, Foint FAO/LAEA Division of Nuclear Techniques in Food and Agriculture, Vienna International Centre, P.O. Box 100, 1400, Vienna, Austria

${ }^{3}$ Laboratory of Genetics, Wageningen University $\&$ Research, Droevendaalsesteeg 1, 6708 PB, Wageningen, The Netherlands

${ }^{4}$ Group for Population and Evolutionary Ecology, FB 02, Institute of Ecology, University of Bremen, Leobener Str. 5, 28359, Bremen, Germany

${ }^{5}$ CABI, Rue des Grillons 1, 2800, Delémont, Switzerland

${ }^{6}$ Animal Breeding and Genomics, Wageningen University E Research, PO Box 338, 6700 AH, Wageningen, The Netherlands

${ }^{7}$ Institut de Recherche en Biologie Végétale, Université de Montréal, 4101 Sherbrooke Est, Montréal, Quebec, Canada, H1X 2 B2

${ }^{8}$ Instituto Valenciano de Investigaciones Agrarias (IVIA), Centro de Protección Vegetal y Biotecnología, Unidad Mixta Gestión Biotecnológica de

Plagas UV-IVIA, Carretera CV-315, Km 10’7, 46113, Moncada, Valencia, Spain

${ }^{9}$ Laboratory of Entomology, Wageningen University E Research, Droevendaalsesteeg 1, 6708 PB, Wageningen, The Netherlands

${ }^{10}$ Biosystematics Group, Wageningen University \& Research, Droevendaalsesteeg 1, 6708 PB, Wageningen, The Netherlands

${ }^{11}$ Department of Genetics, Estructura de Recerca Interdisciplinar en Biotecnología i Biomedicina (ERI-BIOTECMED), Unidad Mixta Gestión

Biotecnológica de Plagas UV-IVIA, Universitat de València, Dr Moliner 50, 46100, Burjassot, Valencia, Spain

${ }^{12}$ Koppert Biological Systems, Veilingweg 14, 2651 BE, Berkel en Rodenrijs, The Netherlands

${ }^{13}$ Department of Biochemistry and Biotechnology, University of Thessaly, Biopolis, 41500, Larissa, Greece

${ }^{14}$ Institut für Populationsgenetik, Vetmeduni Vienna, Veterinärplatz 1, 1210, Vienna, Austria

${ }^{15}$ Vienna Graduate School of Population Genetics, Vetmeduni Vienna, Veterinärplatz 1, 1210, Vienna, Austria

${ }^{16}$ INRA, CNRS, UMR 1355-7254, 400 Route des Chappes, BP 167 06903, Sophia Antipolis Cedex, France

${ }^{17}$ Kearney Agricultural Research and Extension Center, University of California Berkeley, 9240 South Riverbend Avenue, Parlier, CA, 93648, USA

${ }^{18}$ Netherlands Institute of Ecology (NIOO-KNAW), Droevendaalsesteeg 10, 6708 PB, Wageningen, The Netherlands

${ }^{19}$ Institute of Entomology, Biology Centre CAS, Branišovská 31, 370 05, Đeské Budějovice, Czech Republic

${ }^{20}$ Faculty of Science, University of South Bohemia, Branišouská 1760, 370 05, Deské Budějovice, Czech Republic

${ }^{21}$ Department of Biology, University of Rochester, Rochester, NT, 14627, USA

${ }^{22}$ cE3c: Centre for Ecology, Evolution, and Environmental Changes, Faculdade de Ciências da Universidade de Lisboa, Edificio C2, Campo Grande, 1749-016, Lisbon, Portugal
}

* Address for correspondence (Tel: +31 639681419; E-mail: k.leung@rug.nl). 


\begin{abstract}
ABSTRAGT
Biological control is widely successful at controlling pests, but effective biocontrol agents are now more difficult to import from countries of origin due to more restrictive international trade laws (the Nagoya Protocol). Coupled with increasing demand, the efficacy of existing and new biocontrol agents needs to be improved with genetic and genomic approaches. Although they have been underutilised in the past, application of genetic and genomic techniques is becoming more feasible from both technological and economic perspectives. We review current methods and provide a framework for using them. First, it is necessary to identify which biocontrol trait to select and in what direction. Next, the genes or markers linked to these traits need be determined, including how to implement this information into a selective breeding program. Choosing a trait can be assisted by modelling to account for the proper agro-ecological context, and by knowing which traits have sufficiently high heritability values. We provide guidelines for designing genomic strategies in biocontrol programs, which depend on the organism, budget, and desired objective. Genomic approaches start with genome sequencing and assembly. We provide a guide for deciding the most successful sequencing strategy for biocontrol agents. Gene discovery involves quantitative trait loci analyses, transcriptomic and proteomic studies, and gene editing. Improving biocontrol practices includes marker-assisted selection, genomic selection and microbiome manipulation of biocontrol agents, and monitoring for genetic variation during rearing and post-release. We conclude by identifying the most promising applications of genetic and genomic methods to improve biological control efficacy.
\end{abstract}

Key words: artificial selection, biological control, genetics, genome assembly, genomics, insect breeding, microbiome, modelling

\title{
CONTENTS
}

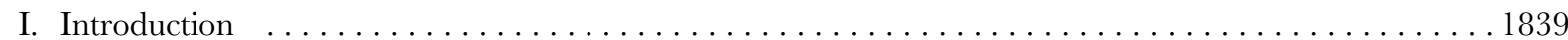

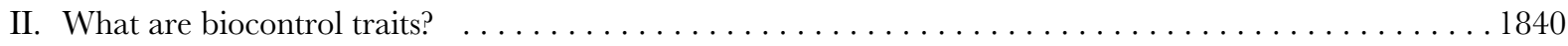

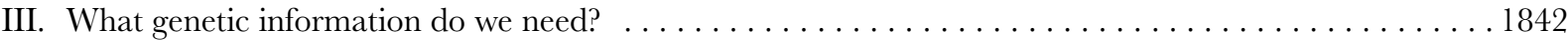

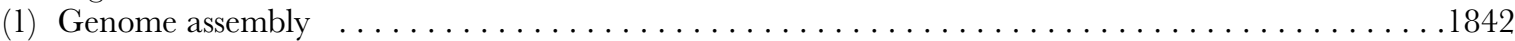

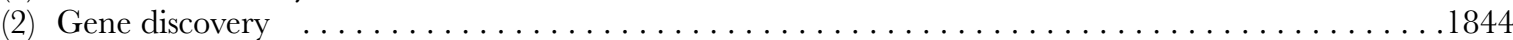

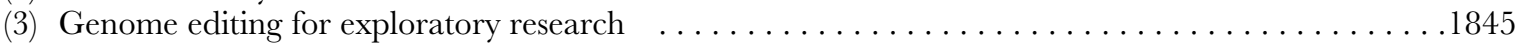

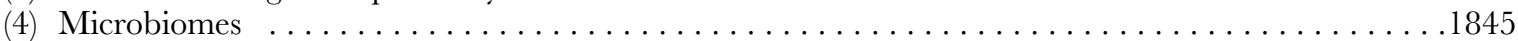

IV. How can genetics be used to improve biological control? $\ldots \ldots \ldots \ldots \ldots \ldots \ldots \ldots \ldots \ldots \ldots \ldots \ldots$

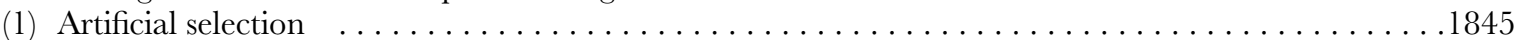

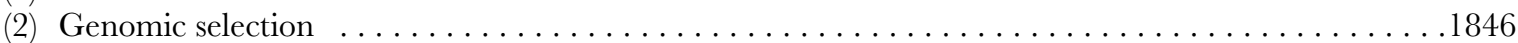

(3) Field monitoring of genetic variation, performance, and ecological risk $\ldots \ldots \ldots \ldots \ldots \ldots \ldots 47$

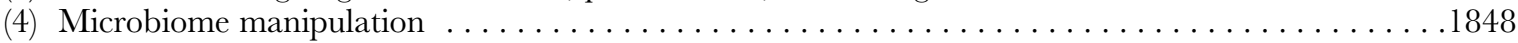

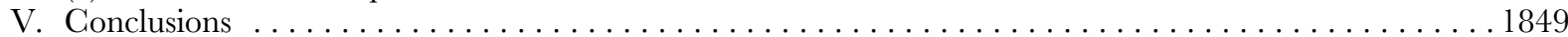

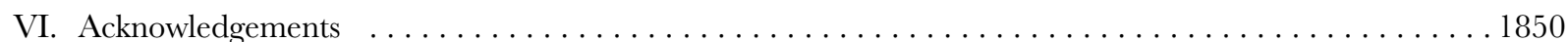

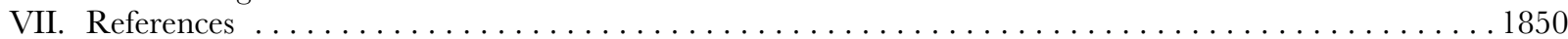

\section{INTRODUCTION}

Biological control (the use of natural enemies to control pests), is arguably the best solution for phasing out large-scale pesticide use (Thomas \& Willis, 1998; Bale, van Lenteren, \& Bigler, 2008). It has been broadly applied for hundreds of years and to great success in both greenhouse and open field systems worldwide (van den Bosch, 1971; Stiling \& Cornelissen, 2005). Most research into the fundamentals of biological control has been from an ecological perspective, focusing on aspects such as optimal foraging and risk monitoring (Wajnberg, Bernstein, \& van Alphen, 2008; Heimpel \& Mills, 2017). As clearly not all programs result in the desired level of pest management, there is considerable room for improvement (Wajnberg, 2004). The reasons for biocontrol programs not always reaching their full potential are manifold, ranging from releasing the wrong control agents, agents not being adapted to local conditions, undesired interactions with the native fauna, and evolutionary changes in the pest species upon invasion.

In the past, the default method for improving biocontrol was to find a more efficient wild species or strain as the biocontrol agent (Hassan \& Guo, 1991; Hassan, 1994; Nomikou et al., 2001; Hoelmer \& Kirk, 2005). However, the Nagoya protocol for Access and Benefit Sharing of Genetics Resources has severely limited international exchange of biological materials, so sourcing more-effective biocontrol agents from the field has become severely restricted (Cock et al., 2010; Deplazes-Zemp et al., 2018; Mason et al., 2018). Moreover, certain geographical regions strictly regulate which agents can be used, e.g. only local strains originating from the region itself (Loomans, 2007; Hunt, Loomans, \& 
Kuhlmann, 2011). Concurrently, demand for more effective biocontrol agents is rising, driven by the growth of the organic food production market (valued at 62.9 billion USD as of 2013; Willer \& Lernoud, 2019; Baker, Green, \& Loker, 2020). The global biological control market was worth 1.7 billion USD in 2015, with sales growing three times faster than pesticides (van Lenteren et al., 2018). Additionally, policy developments have aimed to reduce synthetic pesticide use (van Lenteren et al., 2018) such as an EU-wide neonicotinoid ban (Gross, 2013; Stokstad, 2018) and continuous curtailment of organophosphate use in the USA and worldwide (Hertz-Picciotto et al., 2018). The rise of the organic market in conjunction with a reduction of pesticide use has resulted in the rapid growth and increased market value of the biocontrol industry (de Clercq, Mason, \& Babendreier, 2011; Dunham, 2015; van Lenteren et al., 2018). It is now more urgent than ever to understand how to improve effectively and efficiently non-native biocontrol agents already in use and to develop novel native biocontrol agents. We review recent developments in the field of biological control that indicate that genetics-based solutions are key (Fig. 1).

For decades, genetic methods have been advocated to improve the efficacy of biocontrol programs (White, Debach, \& Garber, 1970; Hoy, 1986; Hopper et al., 1993; Narang, Bartlett, \& Faust, 1993; Nunney, 2003; Routray et al., 2016; Kruitwagen, Beukeboom, \& Wertheim, 2018; Lirakis \& Magalhães, 2019). Significant genetic variation has been demonstrated in several key life-history and behavioural traits of potential biocontrol agents (Hoy, 1985; Rousch, 1990; Hopper et al., 1993; Wajnberg, 2004; Ferguson, 2020). However, despite its proven application in crop and livestock breeding, there have been few attempts to improve biocontrol agents through genetic means. We currently witness a revival of the idea to apply genetics to the improvement of biocontrol programs, by exploiting intraand interspecific variation (Lommen, de Jong, \& Pannebakker, 2017; Kruitwagen et al., 2018), performing experimental evolution (Lirakis \& Magalhães, 2019), adapting the microbiome for improved rearing methods (Ras et al., 2017; Koskinioti et al., 2020a, 2020b), and by population and field-monitoring of released agents (Roderick \& Navajas, 2003; Stouthamer \& Nunney, 2014; Coelho et al., 2016). Notably, these methods all employ classic genetics principles within a species' existing gene pool, distinguishing them from genetically modified organisms (GMOs) that have DNA from foreign organisms introduced into their genomes. That means that the methods discussed here comply with the requirements of the organic food industry and any policies that limit or prohibit GMO use (Gomiero, Pimentel, \& Paoletti, 2011). Next to genetic applications, we need an evolutionary perspective on the sustainability and risks of biocontrol programs, for example to enable predictions of future adaptations of pests and agents (Hufbauer \& Roderick, 2005; Szúcs et al., 2019). Finally, application of genetics and genomics in biocontrol programs cannot be evaluated without considering the role of environmental and ecological processes (Thrall et al., 2011).
We first identify which organismal traits are important for biological control and should therefore be targeted for improvement (so-called 'biocontrol traits'). Next, we present the current state and future prospects of using genetic and genomic methods towards that aim. We consider these methods from evolutionary and ecological contexts, that is how these methods can realistically operate in long-term breeding programs and in the field (Fig. 2). Because of their prevalence and economic importance (van Lenteren et al., 2018), we focus on programs using arthropod biocontrol agents, although these universal genetics principles overlap with other agents (e.g. nematodes, fungi, bacteria). Although the most common form of biological control is augmentative (the recurrent release of a biocontrol agent population not expected to establish permanently, or to supplement an existing population), the methods discussed here can also be applied to classical biological control (release of a new agent with the intention of establishing a self-sustaining population and level of pest control in the area of the pest) and conservation biological control (conserving natural habitat to increase populations of natural enemies). As genomics are key to many of these methods, we provide a key on how to obtain genomebased resources in specific biocontrol contexts. We conclude by reviewing present uses and forecasting applications of the most promising genetic and genomic methods in the future.

\section{WHAT ARE BIOGONTROL TRAITS?}

One of the prime reasons preventing the uptake of genetic improvements of biocontrol agents is difficulty in deciding which traits to optimize. Candidate traits can be roughly subdivided into pest-suppression ability, adaptation to abiotic factors, reducing ecological risk, and improving mass production or storage [see Kruitwagen et al. (2018) and Bielza et al. (2020) for a comprehensive overview]. For some traits, such as pest killrate, the direction of improvement is apparent as killing more pests is a primary determinant of biocontrol success (Stiling \& Cornelissen, 2005). However, for other traits, the direction to take is less obvious. For example, most biocontrol agents attack hosts/prey that are clumped in patches in the environment. Would it be more effective for the agent to clear patches completely before moving on, or to disperse rapidly to protect a larger total crop area (Wajnberg, Roitberg, \& Boivin, 2016; Plouvier \& Wajnberg, 2018)? The optimal strategy depends on the specific ecological circumstances faced by the biocontrol agent and the economic harm inflicted by pest species at low density. Optimality models based on behavioural ecology can provide important insights into the critical characteristics of natural enemies for successful biological control (Mills \& Kean, 2010; Wajnberg et al., 2016; Lommen et al., 2017). Recently, Plouvier \& Wajnberg (2018) developed a general modelling framework that identifies key biocontrol agent lifehistory traits from an economical perspective. For dispersal- 

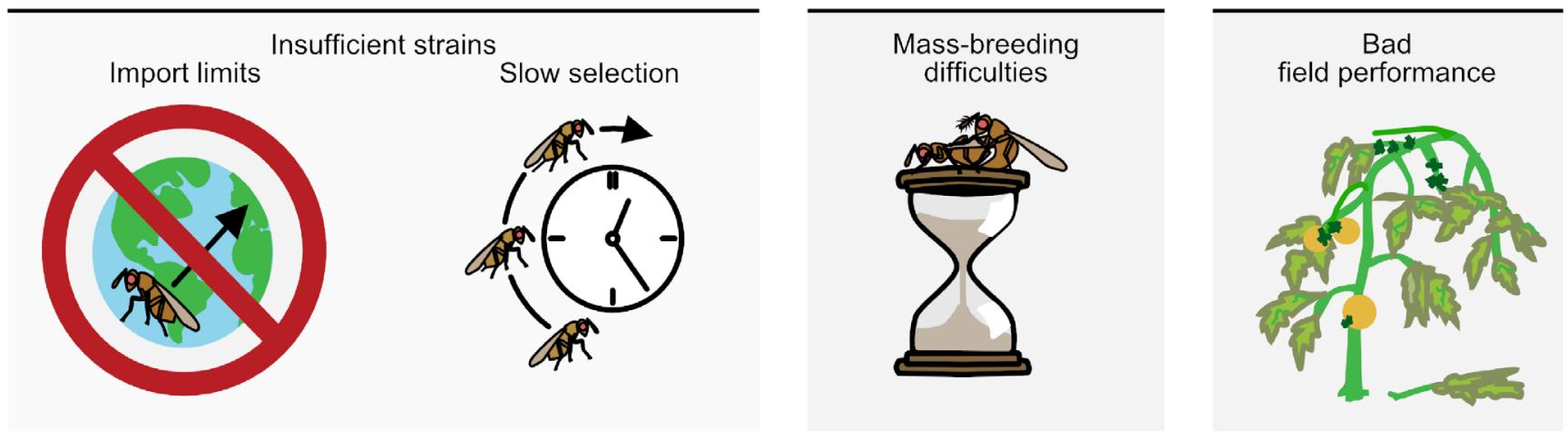

\section{Genetic solutions}

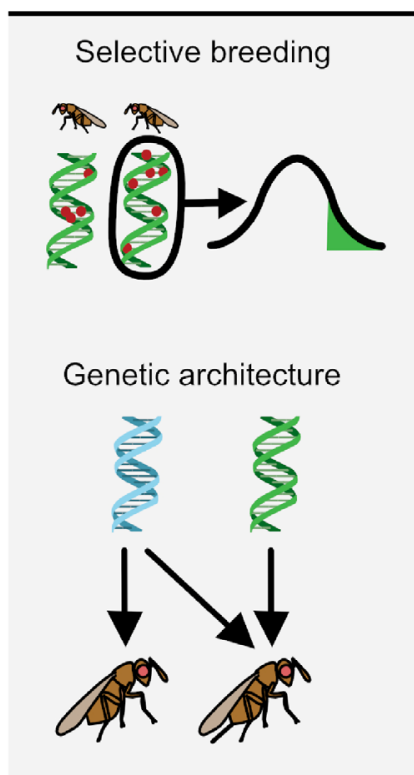

\begin{abstract}
ID of good biocontrol agents
\end{abstract}

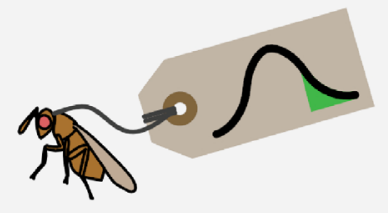

Modelling trait effectiveness

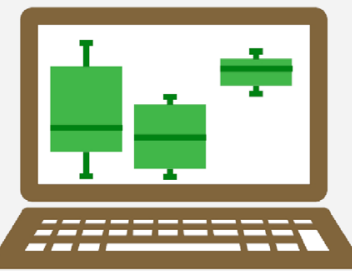

ID of good mass-breeders

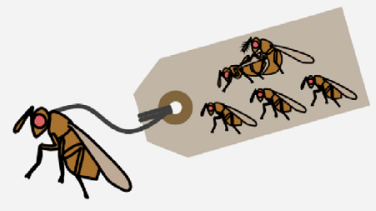

Probiotics

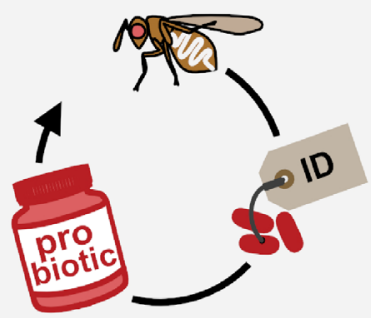

ID of good field performers

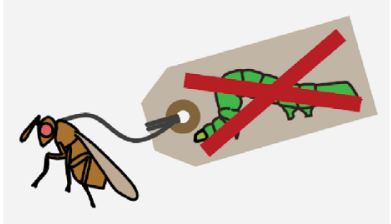

Marker-assisted field monitoring

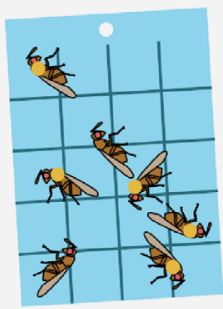

\section{Desired outcome}

Improved strains

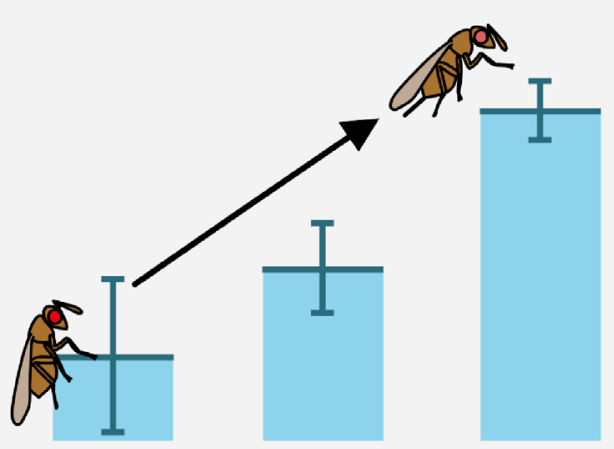

Efficient mass- breeding

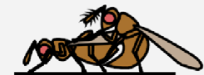

策

为

期

的成

的然

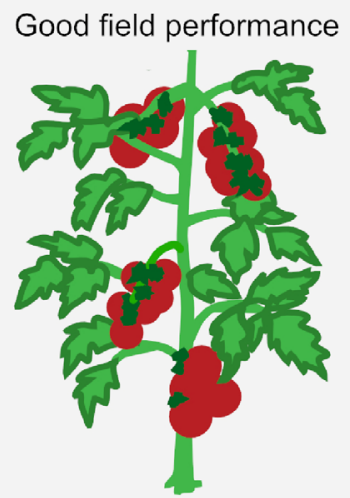

Fig 1. Overview of the potential of genetic methods to address biocontrol challenges.

and-predation simulations, two different optimized life-history strategies for the agents were found to result in higher potential economic returns, differing in plant-leaving decision and host handling time of the biocontrol agent, but also in their respective fecundity, longevity, and dispersal ability. Such a general modelling framework can be parameterised for biocontrol Society. 


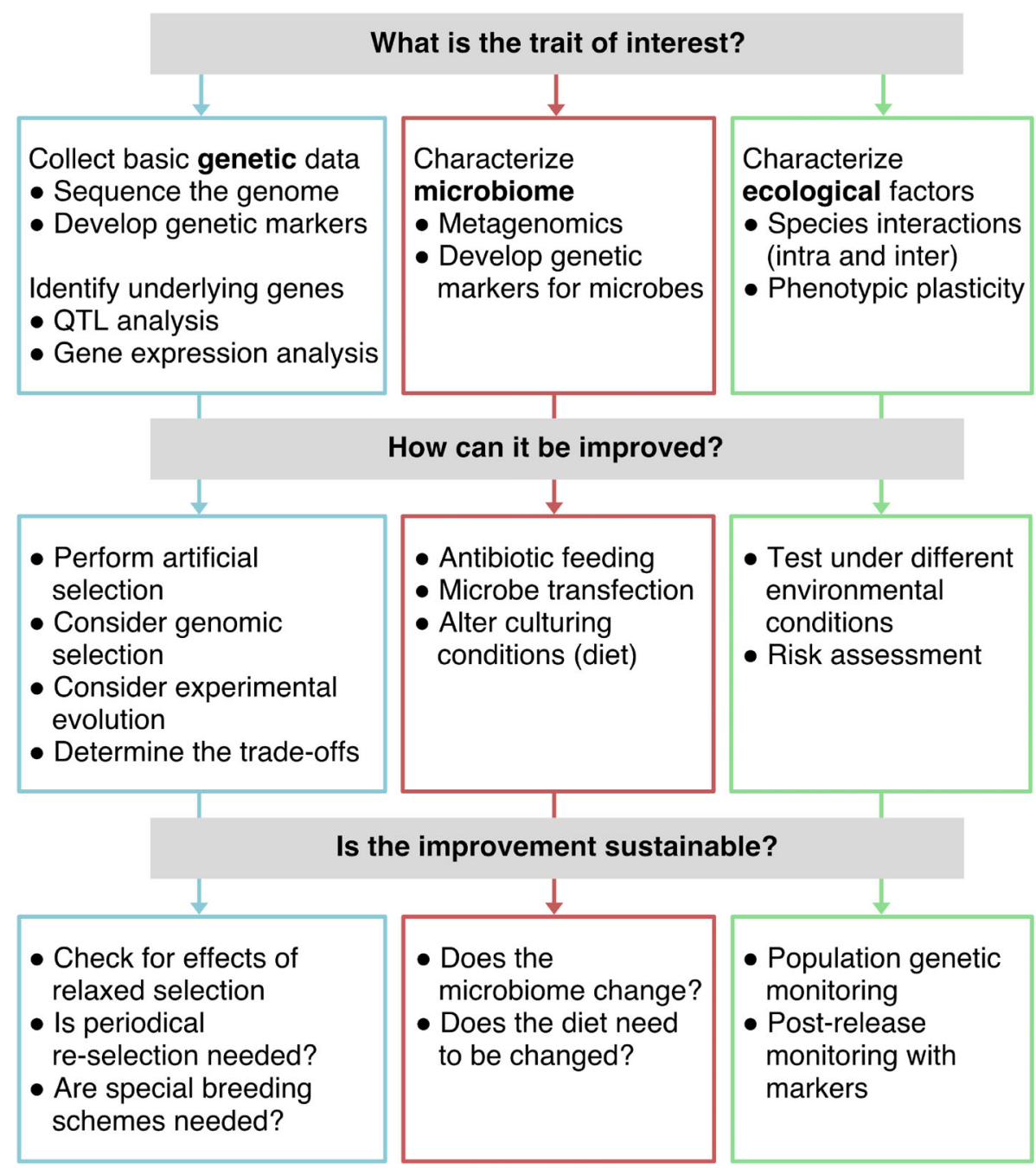

Fig 2. Guide to the use of genetic methods in research and development, sorted according to research question. QTL, quantitative trait locus.

species with different biology (including parasitoids and predators) and different ecological situations to help identify the key traits to target for genetic improvement.

A key requirement for biocontrol traits to be targeted for selection is significant heritability (the proportion of the total phenotypic variation among individuals that is due to additive genetic variation), which allows a trait to be improved by (artificial) selection. The amount of standing genetic variation depends on the type of trait and its genetic architecture, which can be defined as the number and location of the loci involved, and their interactions (such as dominance, epistasis and pleiotropy). Traits closely associated with fitness that are important for biocontrol, such as life-history and behavioural traits (Mousseau \& Roff, 1987; Wajnberg, 2004; Lommen et al., 2017; Kruitwagen et al., 2018; Xia et al., 2020), typically have lower heritabilities than physiological and morphological traits (Mousseau \& Roff, 1987). The amount of genetic variation for biocontrol traits is currently poorly investigated and insufficiently known. For example, in a recent review of arthropod biocontrol literature, of 2927 articles identified as investigating genetics of biocontrol traits, only 69 reported data on genetic variation (Ferguson, 2020). Selection of low-heritability traits towards optimal values is possible, but the efficiency of this process depends on a trait's genetic architecture. It is therefore of key importance to uncover the genetic architecture of biocontrol traits if we aim efficiently to improve them.

\section{WHAT GENETIC INFORMATION DO WE NEED?}

\section{(1) Genome assembly}

Assembling a genome for a biocontrol agent of interest vastly expands the possibilities for generating new knowledge on 
the genetic architecture of biocontrol traits. A reference genome facilitates studies that focus on gene expression analyses, targeted gene editing, and marker-informed selection. Although producing a high-quality genome (high coverage, few gaps) is often portrayed as an essential goal (Bentley, 2006; Faino \& Thomma, 2014), a high-level resolved genome may often not be required. Instead, sequences may be collected, assembled, and annotated to the level required for a specific project, and the genome can later be improved to the level desired by other parties (Papanicolaou et al., 2017). In other words, in more applied circumstances, such as biological control, the aim may be a 'good-enough' genome rather than a high-quality genome. Also, some applications can already be realised with an incomplete genome, including the quick generation of molecular markers such as microsatellites (Grbić et al., 2011; Abe \& Pannebakker, 2017; Kamimura et al., 2019) for low-cost analysis of genetic variation (Baker, Loxdale, \& Edwards, 2003; Paspati et al., 2019) and linkage map construction (Beukeboom et al., 2010; Niehuis et al., 2010).

Genome assembly goes through various stages: sequencing from an inbred stock or a single individual, aligning the sequences into an assembly, and annotating the assembly with protein-coding information (Ekblom \& Wolf, 2014). Although still requiring a considerable amount of labour and funding, recent technological advances have lowered the cost of sequencing a genome considerably (Wetterstrand, 2019). In the context of biological control, successfully producing a workable genome within one's budget and objectives requires careful strategy. For example, for many biocontrol agent species, the amount of DNA extracted from a single individual (because of small body size) is insufficient for sequencing a genome (Richards \& Murali, 2015; Cruaud et al., 2019). Pooling many genetically identical individuals is a solution, but how to obtain such a sample varies among species; this is easier and has been done, for instance, with isofemale lines of haplodiploid parasitoids (Werren et al., 2010; Geib et al., 2017; Ferguson et al., 2020) but can be more challenging for species that are difficult to inbreed (e.g. ladybirds; Facon et al., 2011). Figure 3 presents a key for deciding which sequencing strategy to use for various biological control situations, accounting for the current state of the technology, the biology of the species, and the objective for assembling the genome.

For relatively large-sized species, such as the parasitoid beetle Aleochara bilineata Gyllenhal, a tissue sample from a single individual female was adequate for producing a highquality reference Illumina-based genome; this was done via a third party (Kraaijeveld et al., 2019). By contrast, a single individual of the minute predatory mite Amblyseius swirskii Athias-Henriot swirskii is inadequate for extracting enough DNA to sequence a genome. A solution was found by pooling enough genetically identical individuals to meet the initial genomic weight requirement, but this required an additional, logistically difficult inbreeding step (Paspati et al., 2019) that was not necessary for A. bilineata. A draft genome was created

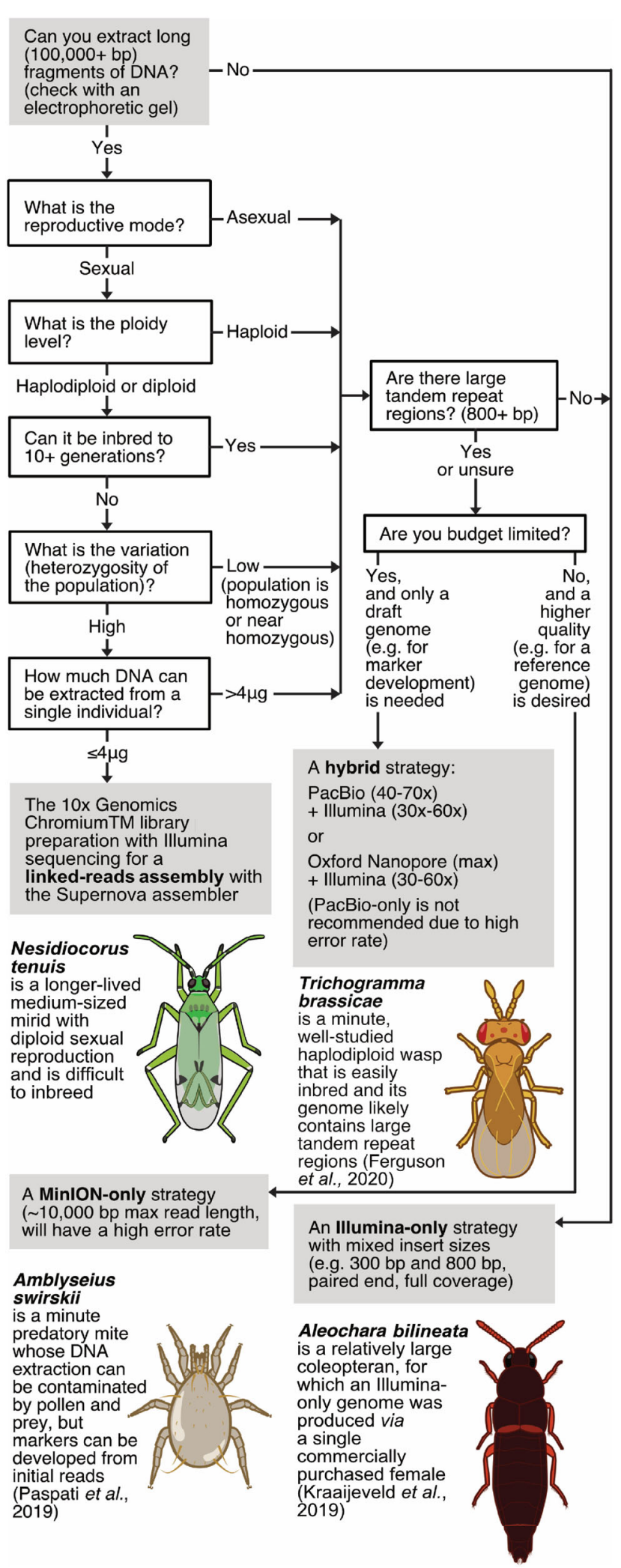

Fig 3. Sequencing strategy key for obtaining genomes of biocontrol agents with selected examples of species. bp, base pair. 
for A. swirskii with inbred individuals using the laboratory benchtop sequencer MinION. This genome was not intended to serve as a high-quality, long-term reference genome for this species, but was used to develop markers affordably for tracking genetic diversity in mass-reared populations (Paspati et al., 2019). This approach had the advantage of flexible in-house troubleshooting with an affordable machine and materials.

\section{(2) Gene discovery}

Mapping genes has a long tradition in breeding and research, particularly using quantitative trait loci studies (QTL) [e.g. maize height (Burr et al., 1988), soybean seed morphology (Mansur et al., 1993), pig fatness and growth (Andersson et al., 1994) and Nasonia parasitoid wasp sex ratio (Pannebakker et al., 2011)]. A QTL study uses crosses of individuals with different extreme phenotypes and links their segregation in offspring to molecular marker data to identify the genetic basis of complex traits (Lynch \& Walsh, 1998; Beukeboom \& Zwaan, 2007). High-throughput sequencing and genome-wide association studies (GWAS) have enabled higher resolution mapping screens (Schlötterer et al., 2014), that is identification of loci with different allele frequencies between two populations with different phenotypes of the target trait (Bastide et al., 2013).

For QTL mapping and GWAS, the statistical power to identify causative variants increases with the number of individuals analysed. In addition, in a QTL approach, power increases with the number of generations invested, but mapping precision is typically lower than GWAS. The genotyping costs can be reduced by relying on sequencing pools of individuals with extreme phenotypes (Pool-GWAS; Schlötterer et al., 2014). This approach was used to create a genome-wide map for body pigmentation in Drosophila melanogaster Meigen (Bastide et al., 2013) and can theoretically be applied to any target trait in any arthropod. Although individuals for these studies can be sourced from commercial biocontrol populations, these tend to be inbred and contain only a fraction of the genetic variation harboured by natural populations (Rasmussen et al., 2018; Paspati et al., 2019). For exploratory studies, sampling from wild populations may be better for collecting sufficiently variable individuals with clear segregation of phenotype, and thus correspondingly distinct genotypes for candidate loci. Alternatively, as it may be legally or logistically difficult to sample multiple natural populations across a large geographic range, commercial strains that are already in use and have contrasting phenotypes may be used instead. For instance, long-established Trichogramma cacoeciae Marchal strains originating from France and Tunisia have higher fecundity under different temperatures (Pizzol et al., 2010), and would be good candidates for investigating loci linked to climate adaptation.

Another approach to delineating the genomic architecture of biocontrol traits is studying gene expression. Sequencing transcriptomes and proteomes, which are complete RNA and protein expression profiles of an organism respectively, has become increasingly easy and affordable. The advantage of gene expression studies is that they delve into contextdependent phenotypes. For example, gene expression differences between the sexes are highly relevant for parasitoid wasps (Wang, Werren, \& Clark, 2015) because females have active genes for host-feeding, envenomation and oviposition that males lack. Spatiotemporal expression pattern differences of protein and transcript quantity, methylation, RNA splicing, and post-translational modification may be responsible for sex-specific phenotypes, and can be used to find trait-linked loci even when genetic sequences are identical between males and females (Wang et al., 2015). Such studies have been used to delineate the architecture of, for example, sex determination (Verhulst, Beukeboom, \& van de Zande, 2010), oviposition (Pannebakker et al., 2013; Cook et al., 2015), and venom composition (de Graaf et al., 2010) in Nasonia vitripennis (Walker), and antennal perception of different olfactory cues, i.e. male mate-searching versus female host-searching in the parasitoids Cotesia vestalis (Haliday) (Nishimura et al., 2012) and Chouioia cunea Yang (Zhao et al., 2016).

Analysis of transcriptomic and proteomic data obtained at different environmental or culturing conditions is also a powerful tool, as it can both identify and quantify patterns of gene expression (Wang et al., 2009). For example, transcriptome analyses of the ladybird Cryptolaemus montrouzieri Mulsant or the parasitic wasps Cotesia typhae FernándezTriana and Lysiphlebus fabarum Marshall show that these biocontrol agents have adapted to alternative prey/hosts by modifying the regulation of genes mainly related to development, digestion, detoxification and virulence (Li et al., 2016; Benoist et al., 2017; Dennis et al., 2017). Mechanisms underlying resistance to certain pesticides in the predatory mite Neoseiulus barkeri Hughes and the ladybird beetle Propylaea japonica (Thunberg) were identified by analysing RNA sequencing (RNAseq) data (Tang et al., 2014; Cong et al., 2016). Transcriptomics may also pave the way to understanding symbiont-mediated resistance to parasitism (Oliver, Moran, \& Hunter, 2005), and help to reverse this effect or to make parasitoids more virulent. Additionally, proteomic analysis of aphid parasitoids Aphidius colemani Haliday that were either exposed to fluctuating high and low temperatures or to constant cold provided insight on genes and proteins involved in surviving temperature extremes, such as those involved in energy metabolism (Colinet et al., 2007). Nutrigenomics (how diet affects gene expression) also has great potential for improving artificial diets for mass rearing of biocontrol agents, and for selecting strains that develop particularly well on such diets (Coudron, Yocum, \& Brandt, 2006; Yocum, Coudron, \& Brandt, 2006). A final interesting application of transcriptomics for biocontrol is to identify the genetic architecture of memory and learning, as parasitoids can be trained to recognise host species (Huigens et al., 2009). Recently, genes in the Ras (rat sarcoma) and phosphoinositide 3-kinase (PI3K) pathways were found 
to be responsible for interspecific differences in Nasonia memory retention (Hoedjes et al., 2014, 2015).

Gene-expression studies can thus contribute to understanding adaptation mechanisms of biocontrol agents to a new environment, prey/host defences or novel hosts. Yet careful control of expression data collection, such as consistent life stage or common garden conditions, is important, as phenotypic plasticity can add noise to analyses. Ultimately, understanding gene expression patterns is essential to allow the preservation of a robust phenotype, or how likely a phenotype is to persist in various agro-ecological environments (Félix \& Barkoulas, 2015).

\section{(3) Genome editing for exploratory research}

Advances in genomics approaches and knowledge have made it possible to modify certain regions in the genome of an organism to study how such modifications are reflected in its phenotype. New phenotypic variants can be generated by knocking-down or knocking-out genes. Knocking-down refers to temporary gene expression inhibition through RNA interference (Pratt \& MacRae, 2009). Knocking-out refers to permanent alteration through the germ line, and the most advanced of these knockout approaches is clustered regulatory interspaced short palindromic repeats (CRISPR) (Hsu, Lander, \& Zhang, 2014). Knocking-down or knocking-out candidate biocontrol trait genes can lead to insights regarding their functions that can be used to optimize selection or breeding of biocontrol agents. For example, they can be used to examine the role of genes in a trait through linkage with the null phenotypes, and those genes can be specifically targeted for selection. Currently, gene-editing technology is exploratory and for fundamental research use, but should not be used in novel biocontrol release programs. Although no external DNA is introduced with knock-down or knock-out, some countries consider gene-editing techniques to be in the same legal category as GMOs (EU; Callaway, 2018) whereas others do not [USA (Kim \& Kim, 2016; Waltz, 2016); Australia (Mallapaty, 2019)]. They are therefore subject to many of the same regulations that vary broadly in restrictiveness, e.g. allowed in the USA versus a complete ban in the EU (reviewed in Alphey \& Bonsall, 2018). In addition, the compatibility of gene-editing with the current 'non-GMO' marketability of biological control is questionable.

\section{(4) Microbiomes}

Currently, there is much interest in the role of the microbiome in organismal functioning. In a biocontrol context, it is known that microbes can generate chemical signals that attract parasitoids to their host, and that bacteria can have a defensive role against parasitoids, such as in aphids (Oliver, Moran, \& Hunter, 2006; Schmid et al., 2012; Rothacher, Ferrer-Suay, \& Vorburger, 2016; Jamin \& Vorburger, 2019; Koskinioti et al., 2019; Dicke, Cusumano, \& Poelman, 2020). Nowadays, universal DNA markers can be applied to characterise the microbiome, that is to identify all bacterial symbionts to at least family or genus level, and their proportionate presence (Ras et al., 2017). This can be used to infer the relative abundance and relative contribution of each symbiont to biocontrol traits. However, despite the enormous attention on the role of microbiomes, we still know very little about whether and how microbes contribute to arthropod life-history traits and biocontrol traits in particular (Janson et al., 2008; Brinker et al., 2019; Gurung, Wertheim, \& Falcao Salles, 2019). In addition, the factors that determine the microbiome composition are often not well known. Such information is important to judge how consistent the microbiome is transgenerationally, and if it can be manipulated through rearing.

\section{HOW GAN GENETIGS BE USED TO IMPROVE BIOLOGIGAL GONTROL?}

\section{(1) Artificial selection}

The traditional approach to improving biocontrol agents has been through artificial selection. Artificial selection exploits inter-individual genetic variation of life-history or behavioural traits. For example, agent species have been selected to improve tolerance to climatic conditions to expand their geographic range of use (White et al., 1970), pesticide resistance (allowing their compatibility with pesticide spraying) (Roush \& Hoy, 1981b; Spollen \& Hoy, 1992), plant adaptation, especially to tomato in strains of Phytoseiulus persimilis Athias-Henriot (Drukker et al., 1997) and development time, to speed up production (Rodriguez-Saona \& Miller, 1995). Rather than performing crosses of individuals with desired traits, experimental evolution exposes populations to specific environmental conditions for several generations and determines the effect on the trait of interest. Although generally successful (Lirakis \& Magalhães, 2019), artificial selection remains underutilised in biological control (Wajnberg, 2004; Lommen et al., 2017; Kruitwagen et al., 2018). There are several reasons for this. One obvious reason is lack of sufficient genetic variation because too few individuals are collected for a source population (but little is known about such unsuccessful attempts in the literature). A second possibility is that once selected, the genetic variation in the selected population will change through stochastic processes such as genetic drift (Roush \& Daly, 1990; Stouthamer, Luck, \& Werren, 1992; Hopper et al., 1993; Wajnberg, 2004). The conclusion has been that to avoid these issues arising from 'selection relaxation', biocontrol agents must be continuously re-selected, which can be economically prohibitive. There is, however, little empirical evidence for this, and a recent study on Drosophila indicates that laboratory populations may not change much in life-history parameters compared to their natural counterparts (Michalak et al., 2019).

Trade-offs between life-history traits are also a factor in biocontrol evolution. Life-history theory poses that an organism has limited resources to allocate to each trait. To select Society. 
for the enhancement of one or more traits, as is the goal in biocontrol breeding, pleiotropic and disadvantageous changes can occur in other traits, and the overall effect on the biocontrol function of the organism can be unpredictable (Stearns, 1989; Roff, 2007). A trade-off may be detrimental for biocontrol because it affects negatively either another trait or another stage in the biocontrol program. For instance, it has been noted that traits corresponding to high yield and ease of use under laboratory and industrial conditions are favourable, but adaptation to captivity may come at the expense of an agent's efficacy in the field (Mackauer, 1976; Hopper et al., 1993; Sørensen, Addison, \& Terblanche, 2012; Sánchez-Rosario et al., 2017). An example is laboratory maintenance negatively impacting female fecundity, body size, host-killing, and host-searching in the parasitoid Muscidifurax raptor Girault and Sanders (Geden et al., 1992). It is also logistically difficult to phenotype complex traits for many biocontrol agents (e.g. measuring total fecundity, total host-killing, dispersal ability, etc.).

However, the means to address many of these problems are at hand. There is evidence, for example, that selection relaxation may not be as problematic as previously believed. Theoretically, if the selection regime is strong enough, the trait goes to fixation in a population, i.e. the entire population will carry the desired trait and it is no longer subject to drift (Falconer \& Mackay, 1996). Moreover, several traits that are selected apparently entail no trade-off in other traits. This is reflected in the value of selected traits being maintained in insect lines even after many generations of no active selection on the trait (e.g. White et al., 1970; Croft \& Meyer, 1973; Roush \& Hoy, 1980; see Lirakis \& Magalhães, 2019).

Key to these solutions is understanding the genetic architecture of the trait under selection, which would allow the combination of individual phenotype selection with molecular genetics through applying marker-assisted selection (Lande \& Thompson, 1990). When, for instance, we know the loci and alleles associated with a desired or undesired target trait, we can breed a more efficient biocontrol agent by selecting for the former and avoiding the latter. Not all trade-offs may be detrimental to biological control. For example early reproduction may come at a cost of longevity (Williams, 1996), but a long life may not be important to a captive population's net productivity if it is frequently supplemented with new, fecund individuals. Knowing the genetic underpinning of trade-offs between traits would assist in understanding and preventing unwanted correlated responses to selection (Fig. 4B). For example, antagonistic pleiotropy (genes operating on multiple traits but in opposing directions) is known for fecundity versus longevity in the melon fly, Zeugodacus cucurbitae (Coquillett) (Miyatake, 1997) and higher larval survival versus lower adult body mass in D. melanogaster (Bochdanovits \& de Jong, 2004); additional studies could uncover these in biocontrol agent species. If there are variable pathways corresponding to different trade-offs, it should be possible to select through one with the fewest unfavourable trade-offs, exploiting the ubiquitous presence of genetic redundancy.

Learning behaviour is another biocontrol trait that responds to selection. Parasitoids (Dukas, 2000; van den Berg et al., 2011; Hoedjes et al., 2014, 2015; Kraaijeveld et al., 2018; Kruidhof et al., 2019), and predators (Rahmani et al., 2009; Schausberger et al., 2010) can be directly selected to recognise pest species better, or indirectly to recognise more efficiently recruitment signals from plants following herbivore attack (tritrophic interactions) (van der Putten et al., 2001; Turlings \& Wäckers, 2004). Juvenile predatory Phytoseiulus persimilis Athias-Henriot can be trained to accept specific prey species and retain this habit throughout its lifetime (Rahmani et al., 2009), as can numerous parasitoid wasps (reviewed in Kruidhof et al., 2019). Delineating the genetic architecture of memory and learning can thus assist in breeding lines that can learn and retain this information better.

Knowledge of the genetic architecture of traits can assist with artificial selection through deliberate targeting of linked genes. This is particularly helpful for traits that are laborious or challenging to phenotype repeatedly. For example, for many arthropods, assaying lifetime reproductive output would require counting thousands of offspring and waiting until the animal dies. In the meantime, work is invested in caring for the next generation whether or not their progenitors prove to have high lifetime fecundity. Instead, rather than the trait itself, selection can target a linked molecular marker, which is called marker-assisted selection (MAS) (Lande \& Thompson, 1990). Identification of candidate genes and QTL through the aforementioned gene discovery methods are key to developing direct markers for genes that control the trait of interest, or markers that are in linkage disequilibrium with the trait and are proximate to the coding gene. Although much work remains to uncover the genetic bases of traits, there are already good results documented for arthropods linking genes and QTL to foraging (Page et al., 2000), grooming (Oxley, Spivak, \& Oldroyd, 2010), and Varroa mite resistance in honey bees (Behrens et al., 2011); fertility in the parasitoid Leptopilina clavipes Hartig (Pannebakker et al., 2004); and sex ratio (Pannebakker et al., 2011), memory retention and olfaction (Hoedjes et al., 2014, 2015), host specificity (Desjardins et al., 2010), and pupal diapause (Paolucci et al., 2016) in $\mathcal{N}$. vitripennis.

\section{(2) Genomic selection}

For complex traits with highly polygenic bases or genes with complicated epigenetic effects, direct and linkage equilibrium MAS may not be possible. In such cases, it is possible to use markers that are linked to a total breeding value instead of any specific phenotype (reviewed in Dekkers, 2004). Genomic selection employs this concept potentially to circumvent the need for proving marker causality. The statistical method of genomic selection uses information from genome-wide DNA-markers such as single nucleotide polymorphisms (SNPs) to select for complex traits 
(A)

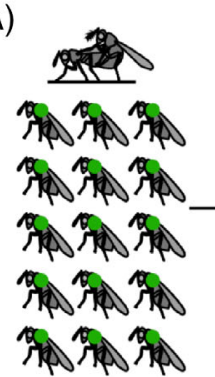
Mass production
+ marker

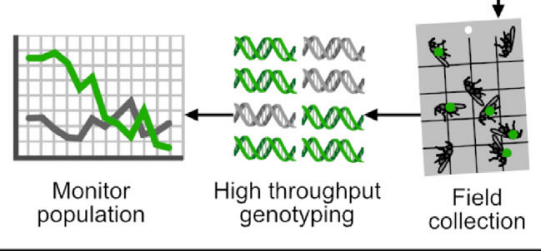

Common practice, now more efficient Relatively easy

(Coelho et al., 2016; Rugman-Jones \& Stouthamer, 2017)
(B)

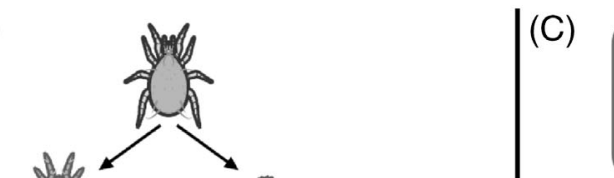

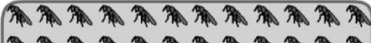

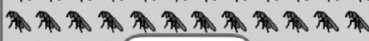

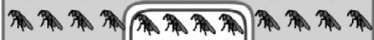

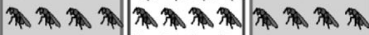

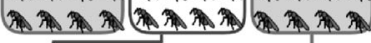
reference population selection candidates

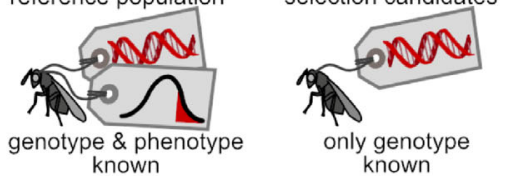
known

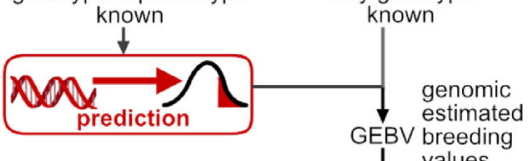
values

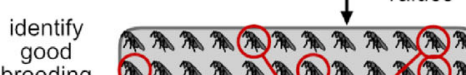
breeding 3 ก candidates $\rightarrow$ ก \& improve
population

Under development, used in livestock Feasible More challenging

(Miyatake, 1997; Bochdanovits \& de Jong, 2004; Nomikou et al., 2003)

Most challenging

(Meuwissen et al., 2001)

Fig 4. Examples of the application of genetic techniques in biocontrol, in increasing order of complexity. (A) Genotyping for field monitoring of released biocontrol agents. (B) Design of optimal rearing strategy based on genetic architecture of traits of interest. (C) Genomic selection to improve polygenic or hard-to-phenotype traits.

(Meuwissen, Hayes, \& Goddard, 2001) (Fig. 4G). This method is particularly helpful when artificial selection (marker assisted or not) is hampered by low heritability either through strong environmental noise and/or low levels of additive genetic variance. The genomic selection method considers markers distributed throughout the whole genome and estimates an effect of each marker, irrespective of the statistical significance of this effect. The total estimated genetic effect of an individual is the sum of the effects of all its markers as the genomic estimated breeding value (GEBV). By including effects of all markers, this method avoids missing a substantial portion of the genetic variance contributed by loci of minor effects, in contrast to methods that aim to identify the causal genes underlying traits. Although genomic selection still requires the collection of both genotypes and phenotypes, this work only needs to be done for the initial reference population and then at infrequent iterations as the predictive power of the reference population is gradually reduced over generations, given the potential evolution of the $\mathrm{G}$ matrix.

An advantage of genomic selection over traditional selection methods is that a higher accuracy of GEBVs can be achieved for traits of low heritability, and for traits that cannot be recorded on the selected candidate itself, but can be predicted through its genotype (Meuwissen et al., 2001). Over the last decade, genomic selection has proved its potential in animal breeding, that is dairy cattle (Hayes et al., 2009; Luan et al., 2009; VanRaden et al., 2009) and pigs (Lopes et al., 2017), but it has not yet been applied to biocontrol agents. Genomic selection methods may be particularly useful because GEBV can be estimated directly from the genotype, without the need for accurate pedigrees that are lacking for most biocontrol agents. One current challenge to genomic selection is the cost of large-scale SNP panels, but these are already undergoing a rapid reduction in difficulty and expense. Also, collection of a sufficient amount of DNA may require sacrificing the selected candidate, but breeding of close relatives, such as offspring or full siblings, may offer a solution.

\section{(3) Field monitoring of genetic variation, performance, and ecological risk}

The availability of genetic markers allows for population genetic analyses, either at a coarse scale such as in the case of microsatellite panels, or at a fine scale such as dense SNP panels based on assembled genomes. A powerful application of population genetics in biocontrol is monitoring of agents released into the field (Fig. 4A), allowing for the monitoring of their genetic variation, field performance, and ecological risk.

An important use of population genetics in biocontrol is the assessment of genetic variation. Loss of genetic variation is expected to occur in all captive populations, through inbreeding, selection, and random genetic drift, even when mass-reared at high numbers (Mackauer, 1976). Although this does not always result in fitness or performance loss [see Hopper et al. (1993) and references therein; de Clercq, Vandewalle, \& Tirry (1998); Facon et al. (2011)], experiments have shown severe effects of inbreeding depression and Society. 
domestication on the reproductive performance of large captive populations of Drosophila (Woodworth et al., 2002) and a Chinese biocontrol population of the parasitoid Binodoxys communis Gahan (Gariepy, Boivin, \& Brodeur, 2014). Specific care should be taken when culturing parasitoid wasps. As haplodiploid species, parasitoids are generally expected to suffer less from inbreeding depression for fitness traits, but in some species a loss of genetic variation for sexdetermination loci results in sterile males, and can lead to extinction of smaller populations (Stouthamer et al., 1992; Zayed \& Packer, 2005; Hein, Poethke, \& Dorn, 2009; Retamal et al., 2016; Zaviezo et al., 2018; Leung, van de Zande, \& Beukeboom, 2019). These potentially large effects on fitness and performance make the monitoring of genetic variation a key part of mass-culturing biocontrol agents. For those species with an assembled genome, whole-genome genotype-by-sequencing (GBS) techniques (Baird et al., 2008) allow for fine-scale population analyses by providing accurate allele frequency estimates to track evolution at a genomic scale and identify genomic regions under selection in contrasting ecological situations (Davey \& Blaxter, 2010). This can also lead the way to unravelling the genetic architecture of relevant biocontrol traits.

A biocontrol agent's performance and ecological risk in the field can also be monitored via genetics methods. For example, for parasitoids, juvenile development often occurs within the host, making them difficult to detect at this stage. Furthermore, many species are difficult to identify via morphology because they belong to mega-diverse groups of minute insects that may not be phylogenetically well resolved (Stouthamer et al., 1999; Sumer et al., 2009; Cruaud et al., 2019). Dispersal, host specificity, and attack rate can all be determined with polymerase chain reaction (PCR) amplification to detect the presence of speciesspecific DNA of parasitoids in hosts (Gariepy et al., 2007, 2008; Stahl et al., 2019). A similar approach has been taken for gut-content analysis to measure predation of the target pest or screen for consumption of non-target species [mostly for predators, e.g. Hoogendoorn \& Heimpel (2001), Thomas et al. (2013), Brown et al. (2014) and Nguyen et al. (2019); but see Rougerie et al. (2011) for a parasitoid example], as well as constructing complex food-webs (Krehenwinkel et al., 2017). These methods can be used to modify biocontrol programmes, for example by selection of more efficacious agents with fewer non-target effects.

Traditional neutral markers have been successfully used for performance monitoring of released strains [e.g. for the parasitoid Trichogramma pretiosum Riley, in which laboratory fecundity was correlated to field efficacy for 35 isofemale lines over 3 days (Coelho et al., 2016) and for the olive fly parasitoid Psittalia lounbysuryi (Silvestri) for ongoing monitoring of a biocontrol programme in southern France (Bon et al., 2008; Malausa et al., 2010)]. However, high-density population genomic methods, such as GBS, allow for more detailed tracking of the introgression of the genetic material into previously released populations (Stouthamer \& Nunney, 2014).
Despite the importance of tracking the fate of released agents and their associated alleles, there has been little effort invested in species-identification assays or genotype-based post-release monitoring in the field, possibly because of its logistic difficulty (Blossey \& Skinner, 1999; Coombs \& McEvoy, 1999; but see Rugman-Jones \& Stouthamer, 2017). Typically, preserved individuals are brought back to the laboratory for DNA extraction, PCR amplification, and sequencing. A recent novel approach allows real-time identification of a biocontrol agent in the field by loop-mediated isothermal amplification (LAMP) (Lee, 2017). This is a low-cost alternative to PCR that can be conducted in a single test tube and at a single temperature. In a biocontrol context, this method has been tested to detect parasitoidism of the Asian chestnut gall wasp Dryocosmus kuriphilus Yasumatsu by Torymus sinensis Kamijo (Colombari \& Battisti, 2016), but it could facilitate all the field-monitoring applications described.

\section{(4) Microbiome manipulation}

Microbiomes may constitute an important target for modifying biocontrol agent performance. The composition of the microbial community of an organism can be altered through rearing conditions (e.g. a probiotic diet), via a breeding regime or by genetic manipulation (Grau, Vilcinskas, \& Joop, 2017; Ras et al., 2017). For example, D. melanogaster fed a probiotic bacterium were less susceptible to infections of pathogenic bacteria (Blum et al., 2013). Sterile male performance was enhanced and Pseudomonas pathogen levels were reduced when the Mediterranean fruit fly Ceratitis capitata (Wiedemann) was fed bacterial supplements (Ami, Yuval, \& Jurkevitch, 2010). Although these studies focused on flies used in the sterile insect technique (mass-releasing sterile males to outcompete wild individuals), the same principles can be applied to biocontrol agents. Supplemented diets, including those with probiotics, can potentially directly improve the performance of mass-reared parasitoids and predators (Nomikou et al., 2003, Ras et al., 2017; Koskinioti et al., 2020a, 2020b), as can feeding on factitious hosts or prey with a specific microbiome indirectly.

It is also possible for host specimens to transmit their microbes to released biocontrol agents and influence their physiology and ecology (Schuler et al., 2013). In such cases, microbial screening with genetic markers would be useful for investigating microbiome shifts that are responsible for phenotype alterations. It is also known that microbes can be responsible for chemical signals that attract parasitoids to their host. This implies that biocontrol agents can potentially be trained using these host microbiomes to be more efficient at finding hosts. In the case of defensive microbes in pest species, exposure to such microbes during development may confer immunity in the next generation (Ras et al., 2017). These applications are, however, still theoretical and will require microbiome determination of specific biocontrol agent-pest pairs, identification of relevant symbionts, and development of methods to optimise their use. 
A specific class of potentially useful symbionts are those that manipulate their hosts' reproduction, such as Wolbachia (Dedeine et al., 2001; Vavre, Fouillet, \& Fluery, 2003; Werren, Baldo, \& Clark, 2008). Wolbachia can cause cytoplasmic incompatibility, which acts as a reproductive barrier among species or strains (Bourtzis et al., 1996; Fouillet et al., 2000; Gotoh, Noda, \& Hong, 2003; Werren et al., 2008). However, it is possible to cure arthropods of Wolbachia with antibiotics, permitting interspecies hybridisation or inter-strain reproduction (Breeuwer \& Werren, 1995). This can, for example, be exploited to create strains that cannot interbreed with native congeners, reducing ecological risk [e.g. predators and parasitoids (Floate, Kyei-Poku, \& Coghlin, 2006; Machtelinckx et al., 2009)].

Wolbachia is also implicated in thelytokous reproduction (female parthenogenesis) in numerous insect species, such as the Drosophila parasitoids Asobara and Leptopilina (Breeuwer \& Werren, 1995; Dedeine et al., 2001; Schidlo et al., 2002; Kremer et al., 2009), aphid parasitoids (Starý, 1999), and Trichogramma species (Stouthamer, Luck, \& Hamilton, 1990; Stouthamer \& Kazmer, 1994). Thelytoky is particularly significant for parasitoids in biocontrol because of its potential for increasing production of host-killling females. In addition, parthenogenesis induction by Wolbachia can be used as a tool for advanced genotypic selection, which exploits the gamete duplication mechanism that underlies parthenogenesis induction by Wolbachia and allows for fast selection of beneficial gene combinations in parasitoids for biocontrol (Russell \& Stouthamer, 2011). In species that do not carry Wolbachia, intentional infection (Yamashita \& Takahashi, 2018) can potentially be used to alter reproduction and life-history traits. Such transfection applications require careful testing, as Wolbachia phenotypes are not always the same between species (Veneti et al., 2012). Also, Wolbachia can reduce the relative number of other potentially beneficial symbiotic bacteria (Audsley, Ye, \& McGraw, 2017; Ye et al., 2017) and conversely, other microbiota can outcompete Wolbachia (Kondo, Shimada, \& Fukatsu, 2005; Goto, Anbutsu, \& Fukatsu, 2006; Hughes, Rivero, \& Rasgon, 2014; Rossi et al., 2015). These competition dynamics within microbiomes (Brinker et al., 2019; Gurung et al., 2019) are an important consideration when releasing manipulated strains into the field, as is the fact that new microbes introduced via hosts may become permanent fixtures in their ecosystem.

\section{GONGLUSIONS}

(1) It is a misconception that genetic solutions to biocontrol problems have been too complex to attempt, explaining the perceived 'lack of progress' in recent decades (Poppy \& Powell, 2004; Lommen et al., 2017; Kruitwagen et al., 2018). Rather, the simpler approach of sourcing superior strains from nature has been more common, but this approach is now severely restricted. Despite their general applicability, animal breeding techniques have not been exploited to their full potential in the biocontrol field.

(2) As biocontrol agents need to perform in a complex ecological environment, this makes it hard to decide which traits to optimise, but we are progressively gaining more knowledge on this, for instance by applying modelling frameworks (Plouvier \& Wajnberg, 2018).

(3) Several novel genetic and genomic approaches are at hand, yet each application requires proper contextualisation for a realistic projection of success. Markerbased methods (such as field-tracking and strain identification) are already being implemented (Fig. 4A). Others are not yet in use but are imminently possible, such as integrating knowledge of genetic architecture to develop more effective breeding programs (Fig. 4B). Still others, such as genomic selection, are currently largely in the theoretical realm. This may be due to novel technologies being prohibitively labour intensive or expensive, or still requiring troubleshooting. The rapid development of genomic sequencing techniques and the resulting cost reductions (Wetterstrand, 2019) will find applications in biocontrol as they have in other biological fields and applications (Handelsman, 2004; Hudson, 2008; Tautz, Ellegren, \& Weigel, 2010; Ashley, 2016; Hohenlohe et al., 2018; Supple \& Shapiro, 2018). Some applications are already successful, such as determining performance of released agents by characterising their diets. Furthermore, even in the more advanced applications, it is likely that a first success will lead to rapid embracement by the scientific community and industry, parallel to the development of the PCR technique and the human genome project. For example, a proofof-principle study on genomic selection for a biocontrol agent would prove its feasibility even if cost and efficiency still need further optimisation (Xia, 2020; Xia et al., 2020) (Fig. 4C).

(4) Novel methodology to uncover the genetic architecture of life-history traits, in combination with increasing investment in research and development by biocontrol companies, will rapidly expand the knowledge base of the biocontrol field. Gene-editing techniques are a useful research tool for delineating this genetic architecture, but as the current biocontrol market depends on a reputation of using more traditional genetics methods, now is not the time to use gene-edited organisms in the field.

(5) Knowledge about genetic variation can be used to design artificial selection programs, either by traditional selective breeding (White et al., 1970; Ram \& Sharma, 1977; Voroshilov, 1979; Roush \& Hoy, 1981a; Hoy, 1986; Rosenheim \& Hoy, 1988; Spollen \& Hoy, 1992; Zhang et al., 2018), or more sophisticated genomic selection (Xia, 2020; Xia et al., 2020) or experimental evolution approaches (Lirakis \& Magalhães, 2019). As strong directional 
selection may also cause genetic impoverishment and increase vulnerability to pathogens and diseases, such approaches should always be designed to maintain sufficient genetic variation.

(6) A caveat is that these approaches do have their limitations; for example, a founding population may lack sufficient genetic variation to select upon (Mackauer, 1976), and even best practices and intentions are not fool-proof (e.g. selection for higher host specificity versus unpredicted host shifts in the field; Follett et al., 2000).

(7) The aim of this review is to stimulate the application of genetic and genomic methodology in next-generation biological control. We hope that it will lead to an increasing awareness of the potential of biocontrol agent breeding among scientists, the biocontrol industry, growers, and the general public.

\section{AGKNOWLEDGEMENTS}

The authors have collaborated within a 4-year EU-funded Marie Skłodovska-Curie Innovative Training Network (ITN) Breeding Invertebrates for Next Generation BioControl. This BINGO Innovative Training Network received funding from the European Union's Horizon 2020 research and innovation programme under the Marie SklodowskaCurie grant agreement No 641456. We thank Martien Groenen and František Marec for their contributions to BINGO, Richard Stouthamer for textual improvements, and Eric Wajnberg for his extensive advice. We are also grateful to the referees, whose clear depth of knowledge and detailed reviews were invaluable.

\section{REFERENGES}

Abe, J. \& Pannebakker, B. A. (2017). Development of microsatellite markers and estimation of inbreeding frequency in the parasitoid wasp Melittobia. Scientific Reports 7, 39879 .

Alphey, N. \& Bonsall, M. B. (2018). Genetics-based methods for agricultural insect pest management. Agricultural and Forest Entomology 20, 131-140.

Ami, E. B., Yuval, B. \& Jurkevitch, E. (2010). Manipulation of the microbiota of massreared Mediterranean fruit flies Ceratitis capitata (Diptera: Tephritidae) improves sterile male sexual performance. ISME fournal 4, 28-37.

Andersson, L., Haley, C. S., Ellegren, H., Knott, S. A., Johansson, M., Andersson, K., Andersson-Eklund, L., Edfors-Lilja, I., Fredholm, M., Hansson, I., et al. (1994). Genetic mapping of quantitative trait loci for growth and fatness in pigs. Science $263,1771-1774$.

Ashley, E. A. (2016). Towards precision medicine. Nature Reviewes Genetics 17, 507-522. Audsley, M. D., Ye, Y. H. \& McGraw, E. A. (2017). The microbiome composition of Aedes aegypti is not critical for Wolbachia-mediated inhibition of dengue virus. PLoS Neglected Tropical Diseases 11, e0005426.

Baird, N. A., Etter, P. D., Atwood, T. S., Currey, M. C., Shiver, A. L., Lewis, Z. A., Selker, E. U., Cresko, W. A. \& Johnson, E. A. (2008). Rapid SNP discovery and genetic mapping using sequenced RAD markers. PLoS One 3, e3376.

BaKer, D. A., Loxdale, H. D. \& Edwards, O. R. (2003). Genetic variation and founder effects in the parasitoid wasp, Diaeretiella rapae (M'intosh) (Hymenoptera: Braconidae: Aphidiidae), affecting its potential as a biological control agent. Molecular Ecology 12, 3303-3311.

Baker, B. P., Green, T. A. \& Loker, A. J. (2020). Biological control and integrated pest management in organic and conventional systems. Biological Control 140, 104095.
Bale, J., van Lenteren, J. \& Bigler, F. (2008). Biological control and sustainable food production. Philosophical Transactions of the Royal Society B: Biological Sciences 363, $761-776$.

Bastide, H., Betancourt, A., Nolte, V., Tobler, R., Stöbe, P., Futschik, A. \& Schlötterer, C. (2013). A genome-wide, fine-scale map of natural pigmentation variation in Drosophila melanogaster. PLoS Genetics 9, e1003534.

Behrens, D., Huang, Q., Gessner, C., Rosenkranz, P., Frey, E., Locke, B., Moritz, R. F. A. \& Kraus, F. B. (2011). Three QTL in the honey bee Apis mellifera L. suppress reproduction of the parasitic mite Varroa destructor. Ecology and Evolution 1, 451-458.

Benoist, R., Chantre, C., Capdevielle-Dulac, C., Bodet, M., Mougel, F., Calatayud, P. A., Dupas, S., Huguet, E., Jeannette, R., Obonyo, J., Odorico, C., Silvain, J. F., Le Ru, B. \& Kaiser, L. (2017). Relationship between oviposition, virulence gene expression and parasitism success in Cotesia typhae nov. sp. parasitoid strains. Genetica 145, 469-479.

Bentley, D. R. (2006). Whole-genome re-sequencing. Current Opinion in Genetics and Development 16, 545-552.

van den Berg, M., Duivenvoorde, L., Wang, G., Tribuhl, S., Bukovinszky, T., Vet, L. E. M., Dicke, M. \& SMid, H. M. (2011). Natural variation in learning and memory dynamics studied by artificial selection on learning rate in parasitic wasps. Animal Behaviour 81, 325-333.

Beukeboom, L. W. \& ZwaAn, B. J. (2007). Genetics. In Insects as Natural Enemies, pp. 167-218. Springer Netherlands, Dordrecht.

Beukeboom, L. W., Niehuis, O., Pannebakker, B. A., Koevoets, T., Gibson, J. D., Shuker, D. M., VAN DE Zande, L. \& GAdAU, J. (2010). A comparison of recombination frequencies in intraspecific versus interspecific mapping populations of Nasonia. Heredity 104, 302-309.

Bielza, P., Balanza, V., Cifuentes, D. \& Mendoza, J. E. (2020). Challenges facing arthropod biological control: identifying traits for genetic improvement of predators in protected crops. Pest Management Science. https://doi.org/10.1002/ps. 5857.

Blossey, B. \& SKINNER, L. (1999). Design and importance of post-release monitoring. In Proceedings of the X International Symposium on Biological Control of Weeds, pp. 4-10.

Blum, J. E., Fischer, C. N., Miles, J. \& Handelsman, J. (2013). Frequent replenishment sustains the beneficial microbiome of Drosophila melanogaster. MBio $\mathbf{4}$, $\mathrm{e} 00860-\mathrm{e} 00813$.

Bochdanovits, Z. \& DE JonG, G. (2004). Antagonistic pleiotropy for life-history traits at the gene expression level. Proceedings of the Royal Society of London, Series B: Biological Sciences 271, S75-S78.

Bon, M. C., Jones, W., Hurard, C., Ris, N., Pickett, C., Estoup, A. \& Fauvergue, X. (2008). Identification of 21 polymorphic microsatellites in the African parasitoid wasp, Psyttalia lounsburyi (Silvestri) (Hymenoptera: Braconidae). Molecular Ecology) Resources 8, 930-932.

VAn DEN Bosch, R. (1971). Biological control of insects. Annual Review of Ecology and Systematics 2, 45-66.

Bourtzis, K., Nirgianaki, A., Markakisa, G. \& Savakis, C. (1996). Wolbachia infection and cytoplasmic incompatibility in Drosophila species. Genetics 144, 1063-1073.

Breeuwer, J. A. J. \& Werren, J. H. (1995). Hybrid breakdown between two haplodiploid species: the role of nuclear and cytoplasmic genes. Evolution 49, 705-717.

Brinker, P., Fontaine, M. C., Beukeboom, L. W. \& Falcao Salles, J. (2019). Host, symbionts, and the microbiome: the missing tripartite interaction. Trends in Microbiology 27, 480-488.

Brown, P. M. J., Ingels, B., Wheatley, A., Rhule, E. L., de Clerce, P., van Leeuwen, T. \& Thomas, A. (2014). Intraguild predation by Harmonia axyridis (Coleoptera: Coccinellidae) on native insects in Europe: molecular detection from field samples. Entomological Science 18, 130-133.

Burr, B., Burr, F. A., Thompson, K. H., Albertson, M. C. \& Stuber, C. W. (1988). Gene mapping with recombinant inbreds in maize. Genetics 118, 519-526.

Callaway, E. (2018). GRISPR plants now subject to tough GM laws in European Union. Nature 560, 16.

de ClercQ, P., Vandewalle, M. \& Tirry, L. (1998). Impact of inbreeding on performance of the predator Podisus maculiventris. BioControl 43, 299-310.

de Clerce, P., Mason, P. G. \& Babendreier, D. (2011). Benefits and risks of exotic biological control agents. Bio Control 56, 681-698.

Cock, M. J. W., van Lenteren, J. C., Brodeur, J., Barratt, B. I. P., Bigler, F., Bolckmans, K., Cônsoli, F. L., Haas, F., Mason, P. G. \& Parra, J. R. P. (2010). Do new access and benefit sharing procedures under the convention on Biological diversity threaten the future of biological control? BioControl 55, 199-218.

Coelho, A., Rugman-Jones, P. F., Reigada, C., Stouthamer, R. \& Parra, J. R. P. (2016). Laboratory performance predicts the success of field releases in inbred lines of the egg parasitoid Trichogramma pretiosum (Hymenoptera: Trichogrammatidae). PLoS One 11, e0146153.

Colinet, H., Nguyen, T. T. A., Cloutier, C., Michaud, D. \& Hance, T. (2007). Proteomic profiling of a parasitic wasp exposed to constant and fluctuating cold exposure. Insect Biochemistry and Molecular Biology 37, 1177-1188. 
Colombari, F. \& Battisti, A. (2016). Native and introduced parasitoids in the biocontrol of Dryocosmus kuriphilus in Veneto (Italy). EPPO Bulletin 46, 275-285.

Cong, L., Chen, F., Yu, S., Ding, L., Yang, J., Luo, R., Tian, H., Li, H., Liu, H. \& RAN, C. (2016). Transcriptome and difference analysis of fenpropathrin resistant predatory mite, Neoseiulus barkeri (Hughes). International Fournal of Molecular Sciences 17, $15-17$.

Cook, N., Trivedi, U., Pannebakker, B. A., Blaxter, M., Ritchie, M. G., Tauber, E., SNEDDON, T. \& ShukER, D. M. (2015). Oviposition but not sex allocation is associated with transcriptomic changes in females of the parasitoid wasp Nasonia vitripennis. G3 Genes $\mid$ Genomes $\mid$ Genetics 5, 2885-2892.

Coombs, E. M. \& McEvor, P. B. (1999). Biological control of plant invaders: regional patterns, field experiments, and structured population models. Ecological Applications 9, 387-401.

Coudron, T. A., Yocum, G. D. \& Brandt, S. L. (2006). Nutrigenomics: a case study in the measurement of insect response to nutritional quality. Entomologia Experimentalis et Applicata 121, 1-14.

Croft, B. A. \& Meyer, R. H. (1973). Carbamate and organophosphorus resistance patterns in populations of Amblyseius fallacis. Environmental Entomology 2, 691-696.

Cruaud, A., Nidelet, S., Arnal, P., Weber, A., Fusu, L., Gumovsky, A., Huber, J., Polaszek, A. \& Rasplus, J. Y. (2019). Optimized DNA extraction and library preparation for minute arthropods: application to target enrichment in chalcid wasps used for biocontrol. Molecular Ecology Resources 19, 702-710.

DAVEY, J. L. \& BlAXTER, M. W. (2010). RADseq: next-generation population genetics. Briefings in Functional Genomics 9, 416-423.

Dedeine, F., Vavre, F., Fleury, F., Loppin, B., Hochberg, M. E. \& Bouletreau, M. (2001). Removing symbiotic Wolbachia bacteria specifically inhibits oogenesis in a parasitic wasp. Proceedings of the National Academy of Sciences of the United States of America 98, 6247-6252.

DeKKERS, J. C. M. (2004). Commercial application of marker- and gene-assisted selection in livestock: strategies and lessons. Fournal of Animal Science 82(E-Suppl), E313-E328.

Dennis, A. B., Patel, V., Oliver, K. M. \& Vorburger, C. (2017). Parasitoid gene expression changes after adaptation to symbiont-protected hosts. Evolution $\mathbf{7 1}$, 2599-2617.

Deplazes-Zemp, A., Abiven, S., Schaber, P., Schaepman, M., Schaepman-Strub, G., Schmid, B., Shimizu, K. K. \& Altermatt, F. (2018). The Nagoya protocol could backfire on the global south. Nature Ecology and Evolution 2, 917-919.

Desjardins, C. A., Perfectti, F., Bartos, J. D., Enders, L. S. \& Werren, J. H. (2010). The genetic basis of interspecies host preference differences in the model parasitoid Nasonia. Heredity 104, 270-277.

Dicke, M., Cusumano, A. \& Poelman, E. H. (2020). Microbial symbionts of parasitoids. Annual Review of Entomology 65, 171-190.

Drukker, B., Janssen, A., Willem, R. \& Sabelis, M. W. (1997). Improved control capacity of the mite predator Phytoseiulus persimilis (Acari: Phytoseiidae) on tomato. Experimental \& Applied Acarology 21, 507-518.

DukAs, R. (2000). Potential fitness consequences of associative learning in a parasitoid wasp. Behavioral Ecology 11, 536-543.

Dunham, W.C. (2015). Evolution and future of biocontrol. In 10th Annual Biocontrol Industry Meeting (ABIM), Basel, Switzerland.

Еквцом, R. \& Wolf, J. B. W. W. (2014). A field guide to whole-genome sequencing, assembly and annotation. Evolutionary Applications 7, 1026-1042.

Facon, B., Hufbauer, R. A. A., Tayeh, A., Loiseau, A., Lombaert, E., Vitalis, R., Guillemaud, T., Lundgren, J. G. G. \& Estoup, A. (2011). Inbreeding depression is purged in the invasive insect Harmonia axyridis. Current Biology 21, 424-427.

Faino, L. \& Thomma, B. P. H. J. (2014). Get your high-quality low-cost genome sequence. Trends in Plant Science 19, 288-291.

FALCONER, D. S. \& MACKAY, T. F. C. (1996). Introduction to Quantitative Genetics. Longman, London.

FÉlix, M. A. \& Barkoulas, M. (2015). Pervasive robustness in biological systems. Nature Reviewes Genetics 16, 483-496.

Ferguson, K. B. (2020). Know your enemy: genomes of biological control agents. $\mathrm{PhD}$ thesis, Wageningen University. https://doi.org/10.18174/511993.

Ferguson, K.B., Kursch-Metz, T., Verhulst, E.C \& Pannebakker, B.A. (2020). Hybrid genome assembly and evidence-based annotation of the egg parasitoid and biological control agent Trichogramma brassicae. G3: Genes $\mid$ Genomes $\mid$ Genetics.

Floate, K. D., Kyei-Poku, G. K. \& Coghlin, P. C. (2006). Overview and relevance of Wolbachia bacteria in biocontrol research. Biocontrol Science and Technology 16, 767-788.

Follett, P. A., Duan, J., Messing, R. H. \& Jones, V. P. (2000). Parasitoid drift after biological control introductions: re-examining Pandora's box. American Entomologist 46, 82-94.

Fouillet, P., Bouletreau, M., Vavre, F., Fleury, F. \& Varaldi, J. (2000). Evidence for female mortality in Wolbachia-mediated cytoplasmic incompatibility in haplodiploid insects: epidemiologic and evolutionary consequences. Evolution 54, 191-200.
Gariepy, T. D., Kuhlmann, U., Gillott, C. \& Erlandson, M. (2007). Parasitoids, predators and PCR: the use of diagnostic molecular markers in biological control of arthropods. Fournal of Applied Entomology 131, 225-240.

Gariepy, T. D., Kuhlmann, U., Gillott, C. \& Erlandson, M. (2008). A large-scale comparison of conventional and molecular methods for the evaluation of hostparasitoid associations in non-target risk-assessment studies. Foumal of Applied Ecology 45, 708-715.

GariepY, V., BoIvin, G. \& Brodeur, J. (2014). Why two species of parasitoids showed promise in the laboratory but failed to control the soybean aphid under field conditions. Biological Control 80, 1-7.

Geden, C. J., Smith, L., Long, S. J. \& Rutz, D. A. (1992). Rapid deterioration of searching behavior, host destruction, and fecundity of the parasitoid Muscidifurax raptor (Hymenoptera: Pteromalidae) in culture. Annals of the Entomological Society of America 85, 179-187.

Geib, S. M., Liang, G. H., Murphy, T. D. \& Sim, S. B. (2017). Whole genome sequencing of the braconid parasitoid wasp Fopius arisanus, an important biocontrol agent of pest tepritid fruit flies. G3 Genes|Genomes |Genetics 7, 2407-2411.

Gomiero, T., Pimentel, D. \& Paoletti, M. G. (2011). Environmental impact of different agricultural management practices: conventional vs. organic agriculture. Critical Reviewes in Plant Sciences 30, 95-154.

Goto, S., Anbutsu, H. \& Fukatsu, T. (2006). Asymmetrical interactions between Wolbachia and Spiroplasma endosymbionts coexisting in the same insect host. Applied and Environmental Microbiology 72, 4805-4810.

Gotoh, T., NodA, H. \& HonG, X. Y. (2003). Wolbachia distribution and cytoplasmic incompatibility based on a survey of 42 spider mite species (Acari: Tetranychidae) in Japan. Heredity 91, 208-216.

de Graaf, D. C., Aerts, M., Brunain, M., Desjardins, C. A., Jacobs, F. J. Werren, J. H. \& Devreese, B. (2010). Insights into the venom composition of the ectoparasitoid wasp Nasonia vitripennis from bioinformatic and proteomic studies. Insect Molecular Biology 19, 11-26.

Grau, T., Vilcinskas, A. \& Joop, G. (2017). Probiotic Enterococcus mundtii isolate protects the model insect Tribolium castaneum against Bacillus thuringiensis. Frontiers in Microbiology $8,1261$.

Grbi, M., van Leeuwen, T., Clark, R. M., Rombauts, S., Rouzé, P., Grbi, V., Osborne, E. J., Dermauw, W., Thi Ngoc, P. C., Ortego, F., HernándezCrespo, P., Diaz, I., Martinez, M., Navajas, M., Sucena, É., Magalhes, S. Nagy, L., Pace, R. M., Djuranovi, S., Smagghe, G., Iga, M., Christiaens, O., Veenstra, J. A., Ewer, J., Villalobos, R. M., Hutter, J. L., Hudson, S. D., Velez, M., Yi, S. V., Zeng, J., Pires-daSilva, A., Roch, F., Cazaux, M., Navarro, M., Zhurov, V., Acevedo, G., Bjelica, A., Fawcett, J. A., Bonnet, E. Martens, C., Baele, G., Wissler, L., Sanchez-Rodriguez, A., Tirry, L., Blais, C., Demeestere, K., Henz, S. R., Gregory, T. R., Mathieu, J., Verdon, L., Farinelli, L., Schmutz, J., Lindquist, E., Feyereisen, R. \& van de Peer, Y. (2011). The genome of Tetranychus urticae reveals herbivorous pest adaptations. Nature 479, 487-492.

Gross, M. (2013). EU ban puts spotlight on complex effects of neonicotinoids. Current Biology 23, R462-R464.

Gurung, K., Wertheim, B. \& Falcao Salles, J. (2019). The microbiome of pest insects: it is not just bacteria. Entomologia Experimentalis et Applicata 167, 156-170.

Handelsman, J. (2004). Metagenomics: application of genomics to uncultured microorganisms. Microbiology and Molecular Biology Reviewes 68, 669-685.

Hassan, S. A. (1994). Strategies to select Trichogramma species for use in biological control. In Biological Control with Egg Parasitoids (eds E. WAJNBERG and S. HASSAN), pp. 55-71. CAB International, Wallingford.

Hassan, S. A. \& GuO, M. F. (1991). Selection of effective strains of egg parasites of the genus Trichogramma (Hym., Trichogrammatidae) to control the European corn borer Ostrinia nubilalis $\mathrm{Hb}$. (Lep., Pyralidae). Foumal of Applied Entomology 111, 335-341.

Hayes, B. J., Bowman, P. J., Chamberlain, A. C., Verbyla, K. \& Goddard, M. E. (2009). Accuracy of genomic breeding values in multi-breed dairy cattle populations. Genetics Selection Evolution 41, 51 .

Heimpel, G. E. \& Mills, N. J. (2017). Biological Control: Ecology and Applications. Cambridge University Press, Cambridge.

Hein, S., Poethke, H. J. \& Dorn, S. (2009). What stops the 'diploid male vortex??-a simulation study for species with single locus complementary sex determination. Ecological Modelling 220, 1663-1669.

Hertz-Picciotto, I., Sass, J. B., Engel, S., Bennett, D. H., Bradman, A. Eskenazi, B., Lanphear, B. \& Whyatt, R. (2018). Organophosphate exposures during pregnancy and child neurodevelopment: recommendations for essential policy reforms. PLoS Medicine 15, e1002671.

Hoedjes, K. M., Smid, H. M., Vet, L. E. M. \& Werren, J. H. (2014). Introgression study reveals two quantitative trait loci involved in interspecific variation in memory retention among Nasonia wasp species. Heredity 113, 542-550.

Hofdjes, K. M., Smid, H. M., Schijlen, E. G. W. M., Vet, L. E. M. \& van Vugt, J. J. F. A. (2015). Learning-induced gene expression in the heads of two Nasonia species that differ in long-term memory formation. BMC Genomics 16, 162. 
Hoelmer, K. A. \& Kirk, A. A. (2005). Selecting arthropod biological control agents against arthropod pests: can the science be improved to decrease the risk of releasing ineffective agents? Biological Control 34, 255-264.

Hohenlohe, P. A., Hand, B. K., Andrews, K. R. \& Luikart, G. (2018). Population genomics provides key insights in ecology and evolution. In Population Genomics (ed. O. RajORA), pp. 483-510. Springer, Cham.

Hoogendoorn, M. \& Heimpel, G. E. (2001). PCR-based gut content analysis of insect predators: using ribosomal ITS-1 fragments from prey to estimate predation frequency. Molecular Ecology 10, 2059-2067.

Hopper, R., Powell, W., Roush, R. T. \& Powell, W. (1993). Management of genetics of biological-control introductions. The Annual Review of Entomology 38, 27-51.

Hoy, M. A. (1985). Improving establishment of arthropod natural enemies. In Biological Control in Agriculture IPM Systems (eds M. Hoy and D. Herzo), pp. 155-166. Academic Press, New York.

Hoy, M. A. (1986). Use of genetic improvement in biological control. Agriculture, Ecosystems and Environment 15, 109-119.

Hsu, P. D., Lander, E. S. \& Zhang, F. (2014). Development and applications of CRISPR-Cas9 for genome engineering. Cell 157, 1262-1278.

Hudson, M. E. (2008). Sequencing breakthroughs for genomic ecology and evolutionary biology. Molecular Ecology Resources 8, 3-17.

Hufbauer, R. A. \& Roderick, G. K. (2005). Microevolution in biological control: mechanisms, patterns, and processes. Biological Control 35, 227-239.

Hughes, G. L., Rivero, A. \& Rasgon, J. L. (2014). Wolbachia can enhance Plasmodium infection in mosquitoes: implications for malaria control? PLoS Pathogens 10, e1004182.

Huigens, M. E., Pashalidou, F. G., Qian, M.-H., Bukovinszky, T., Smid, H. M., van Loon, J. J. A., Dicke, M. \& Fatouros, N. E. (2009). Hitch-hiking parasitic wasp learns to exploit butterfly antiaphrodisiac. Proceedings of the National Academy of Sciences of the United States of America 106, 820-825.

Hunt, E. J., Loomans, A. J. M. \& Kuhlmann, U. (2011). An international comparison of invertebrate biological control agent regulation: what can Europe learn? In Regulation of Biological Control Agents, pp. 79-112. Springer Netherlands, Dordrecht.

JAMIN, A. R. \& Vorburger, C. (2019). Estimating costs of aphid resistance to parasitoids conferred by a protective strain of the bacterial endosymbiont Regiella insecticola. Entomologia Experimentalis et Applicata 167, 252-260.

Janson, E. M., Stireman, J. O., Singer, M. S. \& Авbot, P. (2008). Phytophagous insectmicrobe mutualisms and adaptive evolutionary diversification. Evolution 62, 997-1012.

Kamimura, Y., Abe, J., Ferreira, R. L. \& Yoshizawa, K. (2019). Microsatellite markers developed using a next-generation sequencing technique for Neotrogla spp. (Psocodea: Prionoglarididae), cave dwelling insects with sex-reversed genitalia. Entomological Science 22, 48-55.

KIM, J. \& KIM, J. S. (2016). Bypassing GMO regulations with CRISPR gene editing. Nature Biotechnology 34, 1014-1015.

Kondo, N., Shimada, M. \& Fukatsu, T. (2005). Infection density of Wolbachia endosymbiont affected by co-infection and host genotype. Biology Letters 1, 488-491.

Koskinioti, P., Ras, E., Augustinos, A. A., Tsiamis, G., Beukeboom, L. W., Caceres, C. \& Bourtzis, K. (2019). The effects of geographic origin and antibiotic treatment on the gut symbiotic communities of Bactrocera oleae populations. Entomologia Experimentalis et Applicata 167, 197-208.

Koskinioti, P., Ras, E., Augustinos, A. A., Beukeboom, L. W., Mathiopoulos, K. D., Caceres, C. \& Bourtzis, K. (2020a). Manipulation of insect gut microbiota towards the improvement of Bactrocera oleae artificial rearing. Entomologia Experimentalis et Applicata 168, 523-540.

Koskinioti, P., Ras, E., Augustinos, A. A., Beukeboom, L. W., Mathiopoulos, K. D., Caceres, C. \& Bourtzis, K. (2020b). The impact of fruit fly gut bacteria on the rearing of the parasitic wasp, Diachasmimorpha longicaudata. Entomologia Experimentalis et Applicata 168, 541-559.

Kraajeveld, K., Oostra, V., Liefting, M., Wertheim, B., de Meijer, E. \& Ellers, J. (2018). Regulatory and sequence evolution in response to selection for improved associative learning ability in Nasonia vitripennis. BMC Genomics 19, 892.

Kraajeveld, K., Neleman, P., Mariën, J., De Meijer, E. \& Ellers, J. (2019). Genomic resources for Goniozus legneri, Aleochara bilineata and Paykullia maculata, representing three independent origins of the parasitoid lifestyle in insects. G3 Genes |Genomes | Genetics 9, 987-991.

Krehenwinkel, H., Kennedy, S., Pekár, S. \& Gillespie, R. G. (2017). A cost-efficient and simple protocol to enrich prey DNA from extractions of predatory arthropods for large-scale gut content analysis by Illumina sequencing. Methods in Ecology and Evolution 8, 126-134.

Kremer, N., Charif, D., Henri, H., Bataille, M., Prévost, G., Kraajjeveld, K. \& Vavre, F. (2009). A new case of Wolbachia dependence in the genus Asobara: evidence for parthenogenesis induction in Asobara japonica. Heredity 103, 248-256.

Kruidhof, H. M., Kostenko, O., Smid, H. M. \& Vet, L. E. M. (2019). Integrating parasitoid olfactory conditioning in augmentative biological control: potential impact, possibilities, and challenges. Frontiers in Ecology and Evolution 7, 84.
Kruttwagen, A., Beukeboom, L. W. \& Wertheim, B. (2018). Optimization of native biocontrol agents, with parasitoids of the invasive pest Drosophila suzukii as an example. Evolutionary Applications 11, 1473-1497.

Lande, R. \& Thompson, R. (1990). Efficiency of marker-assisted selection in the improvement of quantitative traits. Genetics 124, 743-756.

LeE, P. L. M. (2017). DNA amplification in the field: move over PCR, here comes LAMP. Molecular Ecology Resources 17, 138-141.

van Lenteren, J. C., Bolckmans, K., Köhl, J., Ravensberg, W. J. \& Urbaneja, A. (2018). Biological control using invertebrates and microorganisms: plenty of new opportunities. Bio Control 63, 39-59.

Leung, K., van de Zande, L. \& Beukeboom, L. W. (2019). Life history traits of the whiting polyploid line of the non-CSD parasitoid Nasonia vitripennis. Entomologia Experimentalis et Applicata 167, 655-669.

Li, H.-S., Pan, C., DE Clerce, P., Ślipiski, A. \& Pang, H. (2016). Variation in life history traits and transcriptome associated with adaptation to diet shifts in the ladybird Cryptolaemus montrouzieri. BMC Genomics 17, 281.

Lirakis, M. \& Mägalhes, S. (2019). Does experimental evolution produce better biological control agents? Entomologia Experimentalis et Applicata 167, 584-597.

Lommen, S. T. E., de Jong, P. W. \& Pannebakker, B. A. (2017). It is time to bridge the gap between exploring and exploiting: prospects for utilizing intraspecific genetic variation to optimize arthropods for augmentative pest control - a review. Entomologia Experimentalis et Applicata 162, 108-123.

Loomans, A. (2007). Regulation of invertebrate Biological Control Agents in Europe: review and recommendations in its pursuit of a harmonised regulatory system. Report EU project REBECA [Regulation of Biological Control Agents].

Lopes, M. S., Bovenhuis, H., Hidalgo, A. M., van Arendonk, J. A. M., Knol, E. F. \& BastiaAnsen, J. W. M. (2017). Genomic selection for crossbred performance accounting for breed-specific effects. Genetics Selection Evolution 49, 51.

Luan, T., Woolliams, J. A., Lien, S., Kent, M., Svendsen, M. \& Meuwissen, T. H. E. (2009). The accuracy of genomic selection in Norwegian red cattle assessed by crossvalidation. Genetics 183, 1119-1126.

Lynch, M. \& Walsh, B. (1998). Genetics and Analysis of Quantitative Traits. Sinauer Associates, Inc, Sunderland.

Machtelinckx, T., van Leeuwen, T., Vanholme, B., Gehesquière, B., Dermauw, W. Vandekerkhove, B., Gheysen, G. \& De Clerce, P. (2009). Wolbachia induces strong cytoplasmic incompatibility in the predatory bug Macrolophus pygmaeus. Insect Molecular Biology 18, 373-381.

MackaUer, M. (1976). Genetic problems in the production of biological control agents. Annual Review of Entomology 21, 369-385.

Malausa, J. C., Blanchet, A., Bon, M. C., Cheyppe-Buchmann, S., GroussierBout, G., Jones, W., Pickett, C., Ris, N., Roche, M., Thaon, M. \& Fauvergue, X. (2010). Introduction of the African parasitoid Psyttalia lounsburyi in south of France for the classical biological control of Bactrocera oleae. IOBC/WPRS Bulletin 59, 163-170.

Mallapaty, S. (2019). Australian gene-editing rules adopt 'middle ground'. Nature Newes. https://www.nature.com/articles/d41586-019-01282-8 [accessed 22 October 2019].

Mansur, L. M., Lark, K. G., Kross, H. \& Oliveira, A. (1993). Interval mapping of quantitative trait loci for reproductive, morphological, and seed traits of soybean (Glycine max L.). Theoretical and Applied Genetics 86, 907-913.

Mason, P. G., Cock, M. J. W., Barratt, B. I. P., Klapwijk, J. N., van Lenteren, J. C., Brodeur, J., Hoelmer, K. A. \& Heimpel, G. E. (2018). Best practices for the use and exchange of invertebrate biological control genetic resources relevant for food and agriculture. BioControl 63, 149-154.

Meuwissen, T. H., Hayes, B. J. \& Goddard, M. E. (2001). Prediction of total genetic value using genome-wide dense marker maps. Genetics 157, 1819-1829.

Michalak, P., Kang, L., Schou, M. F., Garner, H. R. \& Loeschcke, V. (2019). Genomic signatures of experimental adaptive radiation in Drosophila. Molecular Ecology 28, 600-614.

Mills, N. J. \& KEAN, J. M. (2010). Behavioral studies, molecular approaches, and modeling: methodological contributions to biological control success. Biological Control 52, 255-262.

Miratake, T. (1997). Genetic trade-off between early fecundity and longevity in Bactrocera cucurbitae (Diptera: Tephritidae). Heredity 78, 93-100.

Mousseau, T. A. \& RofF, D. A. (1987). Natural selection and the heritability of fitness components. Heredity 59, 181-197.

Narang, S. K., Bartlett, A. C. \& Faust, R. M. (1993). Applications of Genetics to Arthropods of Biological Control Significance. CRC Press, Boca Raton.

Nguyen, V. H., Jonckheere, W., Nguyen, D. T., de Moraes, G. J., van Leeuwen, T. \& De ClerQ, P. (2019). Phytoseiid mites prey effectively on thrips eggs: evidence from predation trials and molecular analyses. Biological Control 137, 104012.

Niehuis, O., Gibson, J. D., Rosenberg, M. S., Pannebakker, B. A., Koevoets, T., Judson, A. K., Desjardins, C. A., Kennedy, K., Duggan, D., Beukeboom, L. W., van De Zande, L., Shuker, D. M., Werren, J. H., Gadau, J., et al. (2010). Recombination and its impact on the genome of the haplodiploid parasitoid wasp Nasonia. PLoS One 5, e8597. 
Nishimura, O., Brillada, C., Yazawa, S., Maffei, M. E. \& Arimura, G. I. (2012). Transcriptome pyrosequencing of the parasitoid wasp Cotesia vestalis: genes involved in the antennal odorant-sensory system. PLoS One 7, e50664.

Nomikou, M., Janssen, A., Schraag, R. \& Sabelis, M. W. (2001). Phytoseiid predators as potential biological control agents for Bemisia tabaci. Experimental and Applied Acarology 25, 271-291.

Nomikou, M., Janssen, A. \& Sabelis, M. W. (2003). Phytoseiid predators of whiteflies feed and reproduce on non-prey food sources. Experimental and Applied Acarology 31, $15-26$.

NunNey, L. (2003). Managing captive populations for release: a population-genetic perspective. In Quality Control and Production of Biological Control Agents: Theory and Testing Procedures (ed. J. C. van Lenteren), pp. 73-88. CABI International, Wallingford.

Oliver, K. M., Moran, N. A. \& Hunter, M. S. (2005). Variation in resistance to parasitism in aphids is due to symbionts not host genotype. Proceedings of the National Academy of Sciences of the United States of America 102, 12795-12800.

Oliver, K. M., Moran, N. A. \& Hunter, M. S. (2006). Costs and benefits of a superinfection of facultative symbionts in aphids. Proceedings of the Royal Society B: Biological Sciences 273, 1273-1280.

Oxley, P. R., SpivaK, M. \& Oldroyd, B. P. (2010). Six quantitative trait loci influence task thresholds for hygienic behaviour in honeybees (Apis mellifera). Molecular Ecology) 19, 1452-1461.

Page, R. E., Fondrk, M. K., Hunt, G. J., Guzman-Novoa, E., Humphries, M. A., Nguyen, K. \& Greene, A. S. (2000). Genetic dissection of honeybee (Apis mellifera L.) foraging behavior. Fournal of Heredity 91, $474-479$.

Pannebakker, B. A., Beukeboom, L. W., Van Alphen, J. J. M., Brakefield, P. M. \& ZwAAn, B. J. (2004). The genetic basis of male fertility in relation to haplodiploid reproduction in Leptopilina clavipes (Hymenoptera: Figitidae). Genetics 168, 341-349.

Pannebakker, B. A., Watt, R., Knott, S. A., West, S. A. \& Shuker, D. M. (2011). The quantitative genetic basis of sex ratio variation in Nasonia vitripennis: a QTL study. Fournal of Evolutionary Biology 24, 12-22.

Pannebakker, B. A., Trivedi, U., Blaxter, M. A., Watt, R. \& Shuker, D. M. (2013). The transcriptomic basis of oviposition behaviour in the parasitoid wasp Nasonia vitripennis. PLoS One 8, e68608.

Paolucci, S., Salis, L., Vermeulen, C. J., Beukeboom, L. W. \& van de Zande, L. (2016). QTL analysis of the photoperiodic response and clinal distribution of period alleles in Nasonia vitripennis. Molecular Ecology 25, 4805-4817.

Papanicolaou, A., Schetelig, M. F., Arensburger, P., Atkinson, P. W., Benoit, J. B., Bourtzis, K., Castañera, P., Cavanaugh, J. P., Chao, H., Childers, C., Curril, I., Dinh, H., Doddapaneni, H. V., Dolan, A., Dugan, S., et al. (2017). The whole genome sequence of the Mediterranean fruit fly, Ceratitis capitata (Wiedemann), reveals insights into the biology and adaptive evolution of a highly invasive pest species. Genome Biology 18, 192.

Paspati, A., Ferguson, K. B., Verhulst, E. C., Urbaneja, A., González-Cabrera, J. \& Pannebakker, B. A. (2019). Effect of mass rearing on the genetic diversity of the predatory mite Amblyseius swirskii Athias-Henriot (Acari: Phytoseiidae). Entomologia Experimentalis et Applicata 167, 670-681.

Pizzol, J., Pintureau, B., Khoualdia, O. \& Desneux, N. (2010). Temperaturedependent differences in biological traits between two strains of Trichogramma cacoeciae (Hymenoptera: Trichogrammatidae). Journal of Pest Science 83, 447-452.

Plouvier, W. N. \& Wajnberg, E. (2018). Improving the efficiency of augmentative biological control with arthropod natural enemies: a modeling approach. Biological Control 125, 121-130.

Poppy, G. M. \& Powell, W. (2004). Genetic manipulation of natural enemies: can we improve biological control by manipulating the parasitoid and/or the plant? In Genetics, Evolution and Biological Control (eds T. EhLer, L. E. SForza and R. MAteIlle), pp. 219-233. CABI International, Wallingford.

Pratt, A. J. \& MACRAE, I. J. (2009). The RNA-induced silencing complex: a versatile gene-silencing machine. Fournal of Biological Chemistry 284, 17897-17901.

van der Putten, W. H., Vet, L. E. M., Harvey, J. A. \& Wäckers, F. (2001). Linking above- and belowground multitrophic interactions of plants, herbivores, pathogens, and their antagonists. Trends in Ecology \& Evolution 16, 547-554.

Rahmani, H., Hoffmann, D., Walzer, A. \& Schausberger, P. (2009). Adaptive learning in the foraging behavior of the predatory mite Phytoseiulus persimilis. Behavioral Ecology 20, 946-950.

Ram, A. \& Sharma, A. K. (1977). Selective breeding for improving the fecundity and sex ratio of Trichogramma fasciatum (Perkins) (Trichogrammatidae: Hymenoptera), an egg parasite of lepidopterous hosts. Entomology 2, 133-137.

Ras, E., Beukeboom, L. W., Cáceres, C. \& Bourtzis, K. (2017). Review of the role of gut microbiota in mass rearing of the olive fruit fly, Bactrocera oleae, and its parasitoids. Entomologia Experimentalis et Applicata 164, 237-256.

Rasmussen, L. B., Jensen, K., Sørensen, J. G., Sverrisdóttir, E., Nielsen, K. L., Overgaard, J., Holmstrup, M. \& Kristensen, T. N. (2018). Are commercial stocks of biological control agents genetically depauperate? - A case study on the pirate bug Orius majusculus Reuter. Biological Control 127, 31-38.
Retamal, R., Zaviezo, T., Malausa, T., Fauvergue, X., Le Goff, I. \& Toleubayev, K (2016). Genetic analyses and occurrence of diploid males in field and laboratory populations of Mastrus ridens (Hymenoptera: Ichneumonidae), a parasitoid of the codling moth. Biological Control 101, 69-77.

Richards, S. \& Murali, S. C. (2015). Best practices in insect genome sequencing: what works and what doesn't. Current Opinion in Insect Science 7, 1-7.

Roderick, G. K. \& Navajas, M. (2003). Genes in new environments: genetics and evolution in biological control. Nature Reviewes Genetics 4, 889-899.

Rodriguez-Saona, C. \& Miller, J. C. (1995). Life history traits in Hippodamia convergens (Coleoptera: Coccinellidae) after selection for fast development. Biological Control 5, 389-396.

Roff, D. A. (2007). Contributions of genomics to life-history theory. Nature Reviewes Genetics 8, 116-125.

Rosenheim, J. A. \& Hoy, M. A. (1988). Genetic improvement of a parasitoid biological control agent: artificial selection for insecticide resistance in Aphytis melinus (Hymenopera: Aphelinidae). Fournal of Economic Entomology 81, 1539-1550.

Rosi, A., Kontarakis, Z., Gerri, C., Nolte, H., Hölper, S., Krüger, M. \& Stainier, D. Y. R. (2015). Genetic compensation induced by deleterious mutations but not gene knockdowns. Nature 524, 230-233.

Rothacher, L., Ferrer-Suay, M. \& Vorburger, C. (2016). Bacterial endosymbionts protect aphids in the field and alter parasitoid community composition. Ecology $\mathbf{9 7}$, $1712-1723$.

Rougerie, R., Smith, M. A., Fernandez-Triana, J., Lopez-Vaamonde, C., Ratnasingham, S. \& Hebert, P. D. N. (2011). Molecular analysis of parasitoid linkages (MAPL): gut contents of adult parasitoid wasps reveal larval host. Molecular Ecology 20, 179-186.

Rousch, R. (1990). Genetic variation in natural enemies: critical issues for colonization in biological control. In Critical Issues in Biological Control (eds M. Mackauer, L. E. EHLER and J. Roland), pp. 563-588. Intercept, Andover.

Roush, R. T. \& DALY, J. C. (1990). The role of population genetics in resistance research and management. In Pesticide Resistance in Arthropods (eds R. T. RousH and B. E. TabashniK), pp. 97-152. Springer, Boston.

Roush, R. \& Hoy, M. (1980). Selection improves Sevin resistance in spider mite predator. Califormia Agriculture 34, 11-14.

Roush, R. T. \& Hoy, M. A. (1981a). Genetic improvement of Metaseiulus occidentalis: selection with methomyl, dimethoate, and carbaryl and genetic analysis of carbaryl resistance. Fournal of Economic Entomology 74, 138-141.

Roush, R. T. \& Hoy, M. A. (1981b). Laboratory, glasshouse, and field studies of artificially selected carbaryl resistance in Metaseiulus occidentalis. Fournal of Economic Entomology 74, 142-147.

Routray, S., Dey, D., Baral, S., Das, A. P. \& Mahantheshwara, B. (2016). Genetic improvement of natural enemies: a review. Agricultural Reviews 37, 325-332.

Rugman-Jones, P. F. \& Stouthamer, R. (2017). High-resolution melt analysis without DNA extraction affords rapid genotype resolution and species identification. Molecular Ecology Resources 17, 598-607.

Russell, J. E. \& Stouthamer, R. (2011). The genetics and evolution of obligate reproductive parasitism in Trichogramma pretiosum infected with parthenogenesisinducing Wolbachia. Heredity 106, 58-67.

Sánchez-Rosario, M., Pérez-Staples, D., Toledo, J., Valle-Mora, J. \& Liedo, P. (2017). Artificial selection on mating competitiveness of Anastrepha ludens for sterile insect technique application. Entomologia Experimentalis et Applicata 162, 133-147.

Schausberger, P., Walzer, A., Hoffmann, D., Rahmani, H., Behaviour, S., June, N., Schausberger, P., Walzer, A., Hoffmann, D. \& Rahmani, H. (2010). Food imprinting revisited: early learning in foraging predatory mites. Behaviour 147, 883-897.

Schidlo, N., Pannebakker, B., Zwaan, B., Beukeboom, L. \& van Alphen, J. (2002). Curing thelytoky in the Drosophila parasitoid Leptopilina clavipes (Hymenoptera: Figitidae). Proceedings of the Section Experimental and Applied Entomology of the Netherlands Entomological Society 13, 93-96.

Schlötterer, C., Tobler, R., Kofler, R. \& Nolte, V. (2014). Sequencing pools of individuals individuals - mining genome-wide polymorphism data without big funding. Nature Reviews Genetics 15, 749-763.

Schmid, M., Sieber, R., Zimmermann, Y. S. \& Vorburger, C. (2012). Development, specificity and sublethal effects of symbiont-conferred resistance to parasitoids in aphids. Functional Ecology 26, 207-215.

Schuler, H., Bertheau, C., Egan, S. P., Feder, J. L., Riegler, M., SchlickSteiner, B. C., Steiner, F. M., Johannesen, J., Kern, P., Tuba, K., Lakatos, F., Köppler, K., Arthofer, W. \& Stauffer, C. (2013). Evidence for a recent horizontal transmission and spatial spread of Wolbachia from endemic Rhagoletis cerasi (Diptera: Tephritidae) to invasive Rhagoletis cingulata in Europe. Molecular Ecology 22, 4101-4111.

Sørensen, J. G., Addison, M. F. \& Terblanche, J. S. (2012). Mass-rearing of insects for pest management: challenges, synergies and advances from evolutionary physiology. Crop Protection 38, 87-94. 
Spollen, K. M. \& Hoy, M. A. (1992). Genetic improvement of an arthropod natural enemy: relative fitness of a carbaryl-resistant strain of the California red scale parasite Aphytis melinus DeBach. Biological Control 2, 87-94.

Stahl, J. M., Gariepy, T. D., Beukeboom, L. W. \& Haye, T. (2019). A molecular tool to identify Anastatus parasitoids of the brown marmorated stink bug. Entomologia Experimentalis et Applicata 167, 692-700.

Starý, P. (1999). Biology and distribution of microbe-associated thelytokous populations of aphid parasitoids (Hym., Braconidae, Aphidiinae). Fournal of Applied Entomology 123, 231-236.

StEARns, S. C. (1989). Trade-offs in life-history evolution. Functional Ecology 3, 259-268.

Stiling, P. \& Cornelissen, T. (2005). What makes a successful biocontrol agent? A meta-analysis of biological control agent performance. Biological Control 34, 236-246.

STOKSTAD, E. (2018). European agency concludes controversial 'neonic' pesticides threaten bees. Science Magazine. https://www.sciencemag.org/news/2018/02/ european-agency-concludes-controversial-neonic-pesticides-threaten-bees [accessed 21 October 2019].

Stouthamer, R. \& Kazmer, D. J. (1994). Cytogenetics of microbe-associated parthenogenesis and its consequences for gene flow in Trichogramma wasps. Heredity 73, 317-327.

Stouthamer, R. \& Nunney, L. (2014). Can neutral molecular markers be used to determine the success of an introduction of a "better" strain into an established population of a biocontrol parasitoid? Fournal of Economic Entomology 107, 483-495.

Stouthamer, R., Luck, R. F. \& Hamilton, W. D. (1990). Antibiotics cause parthenogenetic Trichogramma (Hymenoptera/Trichogrammatidae) to revert to sex. Proceedings of the National Academy of Sciences of the United States of America 87, 2424-2427.

Stouthamer, R., Luck, R. F. \& Werren, J. H. (1992). Genetics of sex determination and the improvement of biological control using parasitoids. Environmental Entomology 21, 427-435.

Stouthamer, R., Hu, J., van Kan, F. J. P. M., Platner, G. R. \& Pinto, J. D. (1999). The utility of internally transcribed spacer 2 DNA sequences of the nuclear ribosomal gene for distinguishing sibling species of Trichogramma. BioControl 43, 421-440.

Sumer, F., Tuncbilek, A. S., Oztemiz, S., Pintureau, B., Rugman-Jones, P. \& Stouthamer, R. (2009). A molecular key to the common species of Trichogramma of the Mediterranean region. BioControl 54, 617-624.

Supple, M. A. \& Shapiro, B. (2018). Conservation of biodiversity in the genomics era. Genome Biology 19, 131.

Szứcs, M., Salerno, P. E., Teller, B. J., Schaffner, U., Littlefield, J. L. \& Hufbauer, R. A. (2019). The effects of agent hybridization on the efficacy of biological control of tansy ragwort at high elevations. Evolutionary Applications 12, 470-481.

TAng, L. D., Wang, X. M., Jin, F. L., Qiu, B. L., Wu, J. H. \& Ren, S. X. (2014). De novo sequencing-based transcriptome and digital gene expression analysis reveals insecticide resistance-relevant genes in Propylaea japonica (Thunberg) (Coleoptea: Coccinellidae). PLoS One 9, e100946.

Tautz, D., Ellegren, H. \& Weigel, D. (2010). Next generation molecular ecology. Molecular Ecology 19, 1-3.

Thomas, M. B. \& WiLlis, A. J. (1998). Biocontrol - risky but necessary? Trends in Ecology and Evolution 13, 325-329.

Thomas, A. P., Trotman, J., Wheatley, A., Aebi, A., Zindel, R. \& Brown, P. M. J. (2013). Predation of native coccinellids by the invasive alien Harmonia axyridis (Coleoptera: Coccinellidae): detection in Britain by PCR-based gut analysis. Insect Conservation and Diversity 6, 20-27.

Thrall, P. H., Oakeshott, J. G., Fitt, G., Southerton, S., Burdon, J. J., Sheppard, A., Russell, R. J., Zalucki, M., Heino, M. \& Ford Denison, R. (2011). Evolution in agriculture: the application of evolutionary approaches to the management of biotic interactions in agro-ecosystems. Evolutionary Applications 4, 200-215.

Turlings, T. C. J. \& WÄCKers, F. (2004). Recruitment of predators and parasitoids by herbivore-injured plants. Advances in Insect Chemical Ecology 2, 21-75.

VanRaden, P. M., van Tassell, C. P., Wiggans, G. R., Sonstegard, T. S., Schnabel, R. D., TaYlor, J. F. \& Schenkel, F. S. (2009). Invited review: reliability of genomic predictions for north American Holstein bulls. Fournal of Dairy Science 92, 16-24.

VAVRe, F., Foulllet, P. \& Fluery, F. (2003). Between- and within-host species selection on cytoplasmic incompatibility-inducing Wolbachia in haploidiploids. Evolution 57, $421-427$.

Veneti, Z., Zabalou, S., Papafotiou, G., Paraskevopoulos, C., Pattas, S., Livadaras, I., Markakis, G., Herren, J. K., Jaenike, J. \& Bourtzis, K. (2012). Loss of reproductive parasitism following transfer of male-killing Wolbachia to Drosophila melanogaster and Drosophila simulans. Heredity 109, 306-312.
Verhulst, E. C., Beukeboom, L. W. \& van de Zande, L. (2010). Maternal control of haplodiploid sex determination in the wasp Nasonia. Science 328, 620-623.

Voroshilov, N. V. (1979). Breeding of thermoresistant lines of Phytoseiulus (Phytoseiulus persimilis AH). Genetika 15, 70-76.

WAJNBERG, E. (2004). Measuring genetic variation in natural enemies used for biological control: why and how? In Genetics, Evolution and Biological Control (eds T. Ehler, L. E. SForza and R. Mateille), pp. 19-37. CABI International, Wallingford.

Wajnberg, E., Bernstein, C. \& van Alphen, J. (2008). Behavioral Ecology of Insect Parasitoids: From Theoretical Approaches to Field Applications. Blackwell Publishing Ltd, Oxford.

Wajnberg, E., Roitberg, B. D. \& Boivin, G. (2016). Using optimality models to improve the efficacy of parasitoids in biological control programmes. Entomologia Experimentalis et Applicata 158, 2-16.

WaltZ, E. (2016). Gene-edited CRISPR mushroom escapes US regulation. Nature 532, 293.

Wang, Z., Mark, G., Snyder, M., Gerstein, M. \& Snyder, M. (2009). RNA-Seq: a revolutionary tool for transcriptomics. Nature Reviewes Genetics 10, 57-63.

WANG, X., Werren, J. H. \& Clark, A. G. (2015). Genetic and epigenetic architecture of sex-biased expression in the jewel wasps Nasonia vitripennis and giraulti. Proceedings of the National Academy of Sciences of the United States of America 112, E3545-E3554.

Werren, J. H., Baldo, L. \& Clark, M. E. (2008). Wolbachia: master manipulators of invertebrate biology. Nature Reviews Microbiology 6, 741-751.

Werren, J. H., Richards, S., Desjardins, C. A., Niehuis, O., Gadau, J., Colbourne, J. K. \& The Nasonia Genome Working Group (2010). Functional and evolutionary insights from the genomes of three parasitoid Nasonia species. Science 327, 343-348.

Wetterstrand, K.A. (2019). DNA Sequencing Costs: Data from the NHGRI Genome Sequencing Program (GSP). https://www.genome.gov/about-genomics/factsheets/DNA-Sequencing-Costs-Data [accessed 10 May 2019].

White, E. B., Debach, P. \& Garber, M. J. (1970). Artificial selection for genetic adaptation to temperature extremes in Aphytis linganensis compere (Hymenoptera: Aphelinidae). Hilgardia 40, 161-192.

Willer, H. \& Lernoud, J. (eds) (2019). The World of Organic Agriculture. Statistics and Emerging Trends 2019. Research Institute of Organic Agriculture (FiBL), Frick, and IFOAM - Organics International, Bonn.

Williams, G. C. (1996). Adaptation and Natural Selection: A Critique of some Current Evolutionary Thought. Princeton University Press, Princeton.

Woodworth, L. M., Montgomery, M. E., Briscoe, D. A. \& Frankham, R. (2002). Rapid genetic deterioration in captive populations: causes and conservation implications. Conservation Genetics 3, 277-288.

XIA, S. (2020). Exploring the potential of genetic improvement of insects: A case study using the haplodiploid parasitoid wasp Nasonia vitripennis. $\mathrm{PhD}$ thesis, Wageningen University. doi: https://doi.org/10.18174/518107

Xia, S., Pannebakker, B. A., Groenen, M. A. M., Zwaan, B. J. \& Bijma, P. (2020). Quantitative genetics of wing morphology in the parasitoid wasp Nasonia vitripennis: hosts increase sibling similarity. Heredity 125, 40-49.

Yamashita, S. \& TAKahashi, K. H. (2018). Artificial transfer of a thelytoky-inducing Wolbachia endosymbiont between strains of the endoparasitoid wasp Asobara japonica (Hymenoptera: Braconidae). Applied Entomology and Zoology 53, 403-409.

Ye, Y. H., Seleznev, A., Flores, H. A., Woolfit, M. \& McGraw, E. A. (2017). Gut microbiota in Drosophila melanogaster interacts with Wolbachia but does not contribute to Wolbachia-mediated antiviral protection. Fournal of Invertebrate Pathology 143, 18-25.

Yocum, G. D., Coudron, T. A. \& Brandt, S. L. (2006). Differential gene expression in Perillus bioculatus nymphs fed a suboptimal artificial diet. Fournal of Insect Physiology 52, 586-592.

Zaviezo, T., Retamal, R., Urvois, T., Fauvergue, X., Blin, A. \& Malausa, T. (2018). Effects of inbreeding on a gregarious parasitoid wasp with complementary sex determination. Evolutionary Applications 11, 243-253.

ZAYEd, A. \& PACKer, L. (2005). Complementary sex determination substantially increases extinction proneness of haplodiploid populations. Proceedings of the National Academy of Sciences of the United States of America 102, 10742-10746.

Zhang, G., Li, Y., Tian, C., Xu, Y., Zhou, H., Huang, J., Wang, J. \& Liu, H. (2018). Intraspecific variations on thermal susceptibility in the predatory mite Neoseiulus barkeri Hughes (Acari: Phytoseiidae): responding to long-term heat acclimations and frequent heat hardenings. Biological Control 121, 208-215.

Zhao, Y., Wang, F., Zhang, X., Zhang, S., Guo, S., Zhu, G., Liu, Q. \& Li, M. (2016). Transcriptome and expression patterns of chemosensory genes in antennae of the parasitoid wasp Chouioia cunea. PLoS One 11, e0148159.

(Received 22 November 2019; revised 16 July 2020; accepted 20 July 2020; published online 14 August 2020) 